\title{
Relationships between microstructural features and mesoscopic fracture density in a Pleistocene till (Konin area, central Poland)
}

\author{
Wojciech Włodarski \\ Institute of Geology, Maków Polnych 16, 61-606 Poznań, e-mail: wojtekw@amu.edu.pl
}

\begin{abstract}
The qualitative and quantitative characteristics of microstructures in a till were analysed with SEM; it was also investigated whether the results depend on the till's mesostructural characteristics. The till, exposed in a few open-cast browncoal mines near Konin in central Poland, is cut by numerous fractures which correspond to Riedel shear patterns, P-type structures and C-S type foliations. The fractures developed as a result of simple shearing induced by movement of the base of the Odranian ice sheet. On the basis of fracture density, two till types are distinguished: coarsely-brecciated till (wide spacing of fractures) and finely-brecciated till (closely spaced fractures). It is found that the fracture density is reflected in the microstructure of the till. The finely-brecciated till is characterised by a high porosity and has predominantly anisometric and fissure-like pores that also show a more clearly preferred orientation than the pores in the coarsely-brecciated till. In contrast, the coarsely-brecciated till has anisometric pores that show a less preferential orientation. The porosity of the coarsely-brecciated till is lower than in the finely-brecciated till.

The finely-brecciated till probably represents a strongly deformed deposit, related in some cases to zones developed along thrusts that cut the till. Positive correlation between the porosity, the spatial arrangement of pores, and the density of fractures suggests a synsedimentary origin of the shear strain. This strain was accommodated by a particulate flow developed within both wide, pervasive zones and narrow, localised zones. The hydraulic conditions within the subglacial shear zone controlled rheological differences within the till during deformation and thus influenced the degree of the microstructure alteration.
\end{abstract}

Keywords: till, shear fractures, microstructures, SEM, rheology

\section{Introduction}

Recent studies of a glacial till by means of a scanning electron microscope (SEM) were focused on two aspects, viz. (1) the morphology of the sand or silt grains (this parameter forms the basis for identification of glacial abrasion and crushing at the bottom of active ice: Mahaney et al., 1996; Hart, 2006; Rose \& Hart, 2007), and (2) the relationships between the microstruc- tural and geotechnical characteristics of the till (e.g. Kaczyński \& Trzciński, 1992; Trzciński \& Kaczyński, 1999; Trzciński, 2008). Only few studies have described thus far microstructures in relation to depositional or deformational conditions in the glacial environment using SEM (Murray \& Dowdeswell, 1992; RuszczyńskaSzenajch et al., 2003; Trzciński, 2003; Kilfeather \& Van der Meer, 2008; Ruszczyńska-Szenajch \& Trzciński, 2009). 
The till microstructures were analysed, both qualitatively and quantitatively, by means of SEM; this investigation was carried out taking mesostructural (outcrop scale) characteristics into account. The glacial till that yielded the samples is exposed in a few open browncoal mines near Konin in central Poland. Its age is Odranian (Włodarski, 2000). Recent studies into its structural characteristics (Włodarski, 2009) show that the till is cut by numerous fractures. According to their geometry and spatial architecture, these fractures correspond to the Riedel shears, P-type structures and C-S type foliations. It is assumed that the fractures developed as a result of simple shearing induced by the movement of the base of the ice sheet. The corresponding directions of the simple shearing and the movement of the Odranian ice sheet suggests that these fractures developed during the Odranian glaciation. No mesostructural data have been noted to determine the moment of till fracturing after its basal melting.

The density of the fractures within the till seems variable, but this has not been studied in detail. The variations in the density of the fractures in the till may reflect the magnitude of the shear strain and thus might be a key parameter for shear-strain reconstruction. For example, this criterion has been used for the recognition of tectonic melanges from other, less deformed, deposits such as dismembered units or broken units (Raymond, 1984). Similarly, the density of the fractures typically increases within fault zones (e.g. Caine et al., 1996). Obviously, the lithology strongly controls the fracture density, that seems particularly related to differences in the competence of the individual beds (Vannucchi et al., 2003). This competence reflects the mechanical properties of a deposit on the basis of its mineral and textural composition, arrangement of grains or clay particles, and their sorting. Additionally, these parameters, which also depend on the degree of consolidation, can influence the porosity of a deposit.

The mechanical properties of a deposit determine not only the values of cohesion and internal friction angle in terms of the CoulombMohr failure criterion, but also may control the permeability. This parameter controls the spatial arrangement of the pore pressure in a de- posit during deformation, and determines the ability of pore water to escape at a rate proportional to the tectonic loading (Maltman, 1994). According to the critical state theory, an overpressure or underpressure of pore water can determine whether strains are brittle and localised within narrow linear zones in a deposit or whether they are accommodated by a more pervasive ductile particulate flow (Bolton et al., 1998). In both cases, the volumetric strains can be manifested by volume changes within shear zones.

If shear strains involve a heavily overpressurized and fairly consolidated deposit, the pore water cannot escape at a rate consistent with the strain rate. Under such conditions, dilatation as a positive volume change (i.e. an increase of the deposit's volume) within narrow discrete shear zones is to be expected. The volumetric strains of a slightly overpressurized and less consolidated deposit can be accommodated by dilatation within more pervasive shear zones. Within an underpressurized deposit, negative volume changes (compaction and thus reduction of the deposit's volume) within more pervasive shear zones is to be expected (Jones \& Addis, 1986; Bolton et al., 1998).

Under both over- and underpressurized conditions, the accommodation of the pervasive shear strains by development of a ductile particulate flow can be enhanced if individual particles of the deposit easily slip and roll with respect to each other (Borradaile, 1981). It is important to note that the sliding friction on particle contacts can be low, as the normal effective stress acting across the contacts is reduced by a high pore-water pressure.

Varying strain patterns, depending on the mechanical properties of a deformed deposit and on the hydraulic conditions within shear zones, can be recognized by means of microscopic evidence of deformation (Arch \& Maltman, 1990; Murray \& Dowdeswell, 1992; Antonellini et al., 1994; Kilfeather \& Van der Meer, 2008). Apart from a preferred particle alignment, the character of the porosity changes is a useful tool to distinguish between brittle, ductile, localised, and pervasive shear strain. Moreover, the volumetric strains within shear zones related to positive volume changes (dila- 
tation) or negative volume changes (compaction) can be reconstructed on this basis.

The present contribution is aimed at establishing relationships between the qualitative and quantitative features analysed at microscale (using SEM) and the density of fractures observed at mesoscale, because such relationships may show the type and degree of transformation of microstructure features during the formation of mesoscopic fractures. It was also investigated whether such correlations result only from more penetrative shears at microscale, or whether they reflect more complex conditions of shear strain controlled by porewater migration. Finally, it was investigated whether a synsedimentary or postsedimentary character of till deformation could thus be established.

\section{Geological background}

The study area is situated within the Kleczew Graben zone in the northern part of the Konin Elevation (Fig. 1). The Kleczew Graben is a young tectonic structure; the major subsidence occurred during the Middle to Late Miocene (Widera, 1998). The subsidence allowed accumulation of a thick unit, the Poznan Formation. This formation consists of Middle Miocene browncoals and Late Miocene clays. Above this formation, four Quaternary units are present: the Jóźwin Glaciofluvial Series (mainly sands with minor amounts of gravels and silts), and three horizons of glacial tills that have been denoted by Stankowski \& Krzyszkowski (1991) as T2, T3 and T4 (Fig. 1). It is assumed that the Jóźwin Glaciofluvial Series

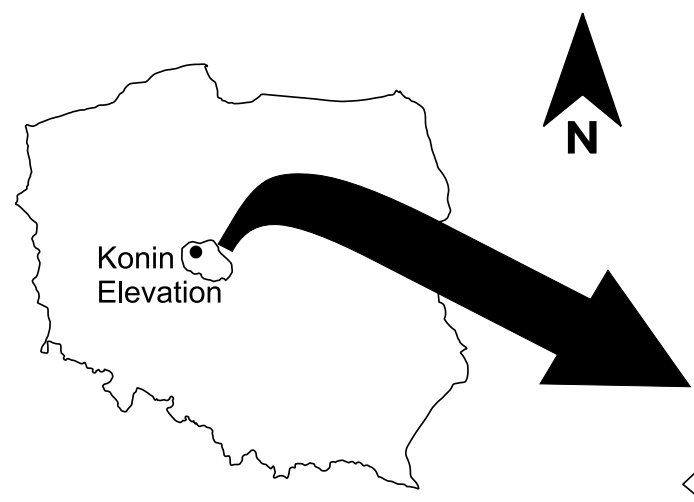

A
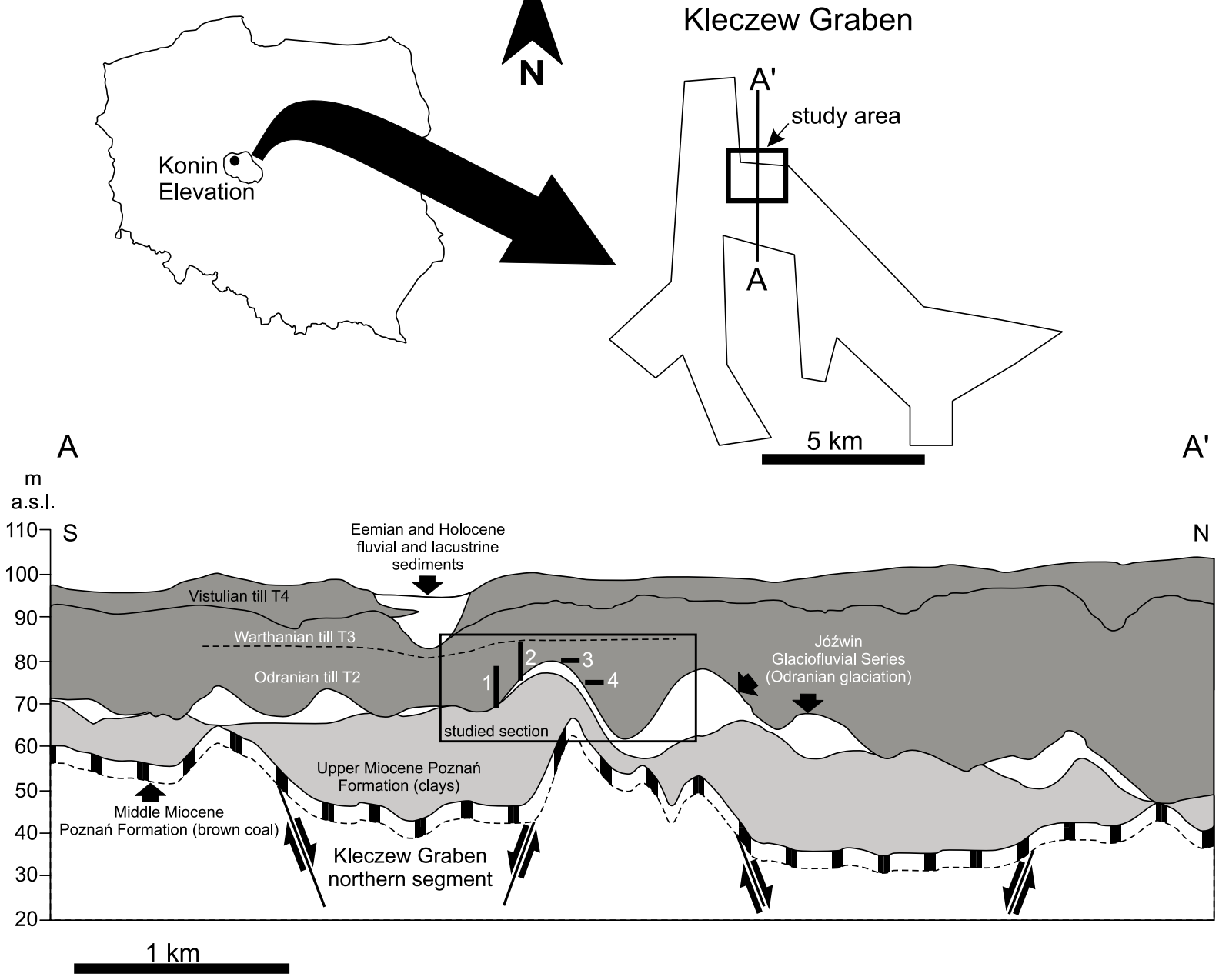

Fig. 1. Study area in the Kleczew Graben, showing the geological cross-section A-A'. Note the position of the vertical and horizontal profiles where detailed mesostructural analyses and sampling for SEM analysis were made. 
and glacial till T2 were deposited during the Odranian glaciation (Włodarski, 2000). The deposition of tills T3 and T4 took place during the Warthanian and Vistulian glaciations, respectively.

The deposits (excluding the T3 and T4 tills and part of the browncoal units of the Poznan Formation) have been disturbed strongly by glacitectonics (Włodarski, 2000, 2009). A geological cross-section (Fig. 1) shows that the glaciotectonic deformations are represented by large undulations of the upper surface of the clays of the Poznan Formation and of the base of till T2. The geometry of the glaciotectonic mesostructures has been analysed in detail along some scarps of the open-cast browncoal mines, where it was found that the deposits older than till T2 were deformed in front of the advanced Odranian ice-sheet; till $\mathrm{T} 2$, in contrast, was deformed subglacially (Włodarski, 2009). The microstructural and mesostructural characteristics of this till T2 are dealt with extensively in the present contribution.
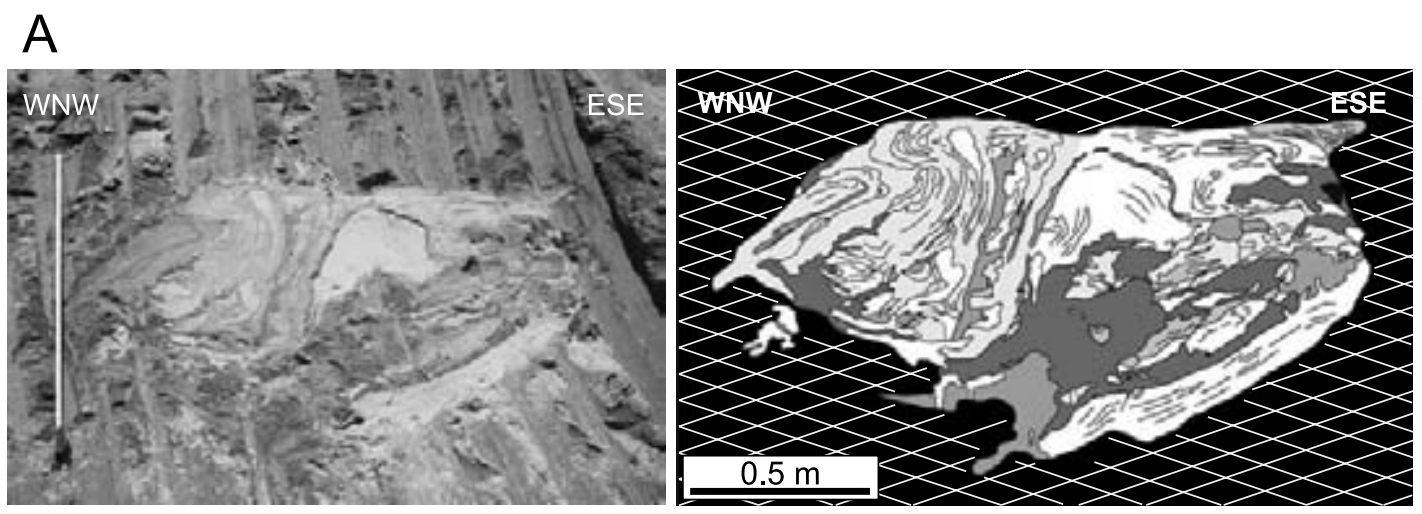

B

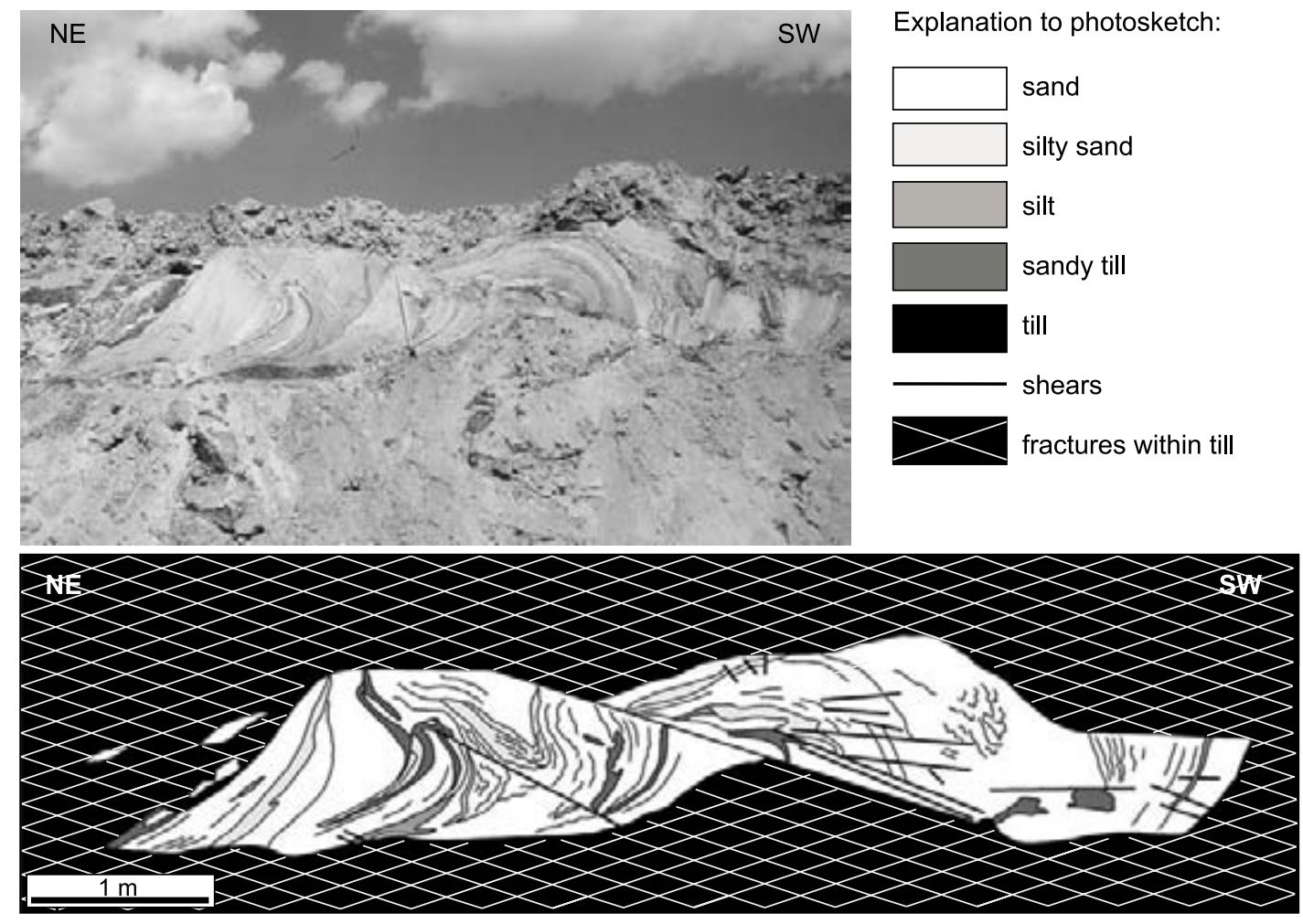

Fig. 2. Examples of blocks that were subglacially deformed by drag folding, flowing and ductile simple shearing. A - Disharmonic fold; B - Recumbent and faulted fold with secondary faults and fractures within the hinge zone. 
According to the mesoscopic structures, this till represents a block-in-matrix mélange (Włodarski, 2009). The matrix consists of darkbrown to grey, silty-clayey massive sand. The blocks embedded in the matrix are represented by large (up to $3 \mathrm{~m}$ ) isolated blocks of older strata composed of silt, sand, gravel and sometimes browncoal. These blocks were subglacially eroded and then melted from the ice bottom, together with the finer particles now forming the mélange matrix. The morphology of the blocks and their internal deformations suggest post-melting subglacial drag folding, flowing and ductile simple shearing (Włodarski, 2000, 2009) (Fig. 2). Additionally, both the blocks and the matrix are cut by numerous fractures with different densities (Fig. 3). Many of these fractures represent the Riedel shears, P-type structures and rarely the C-S type foliations developed by subglacial simple shearing (Włodarski, 2009). Some fractures cut across the blocks, causing offsets ranging from centimetres to tens of metres between individual block fragments (Fig. 2B), thus confirming the post-melting deformation of the blocks.
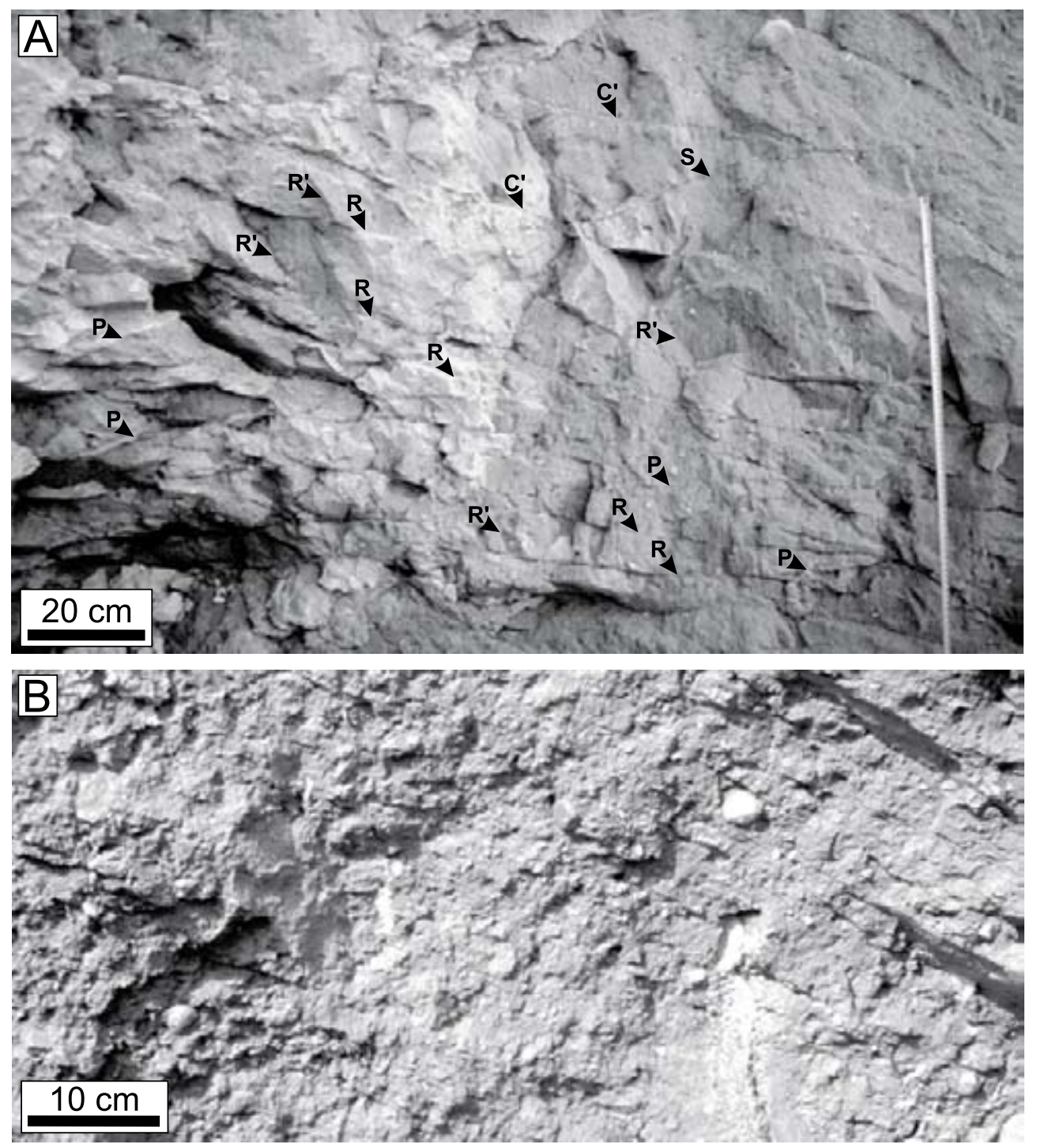

Fig. 3. Mesostructural types of glacial till T2 in relation to fracture density and pattern.

A - Coarsely-brecciated till with widely spaced fractures. These fractures correspond to Riedel shears $\left(R, R^{\prime}\right), P$ structures and C-S foliation; B - Finely-brecciated till with very closely spaced anastomosing fractures. Note the more regular sheet-like fractures in the top right of the image; these are related to the transitional zone with the coarsely-brecciated till (outside of image). 


\section{Research methods and terminology}

\section{Sampling procedure and mesostructural analysis}

Twenty-eight oriented and undisturbed samples were collected for SEM analysis. The sampling was usually made along both the two vertical and the two horizontal profiles indicated in Figure 1. The vertical profiles were extended from the basis of the till $\mathrm{T} 2$ to its top (Figs. 4, 5). The horizontal profiles extend across two mesoscopic thrust planes, including both their hanging walls and foot walls (Figs. 6, 7). A few samples were also collected from iso- lated sites where till $\mathrm{T} 2$ is in contact with older deposits of different lithology and permeability: browncoal, clay, silt and sand. Additionally, the density of the fractures in the till was defined during sampling. On the basis of the size of 'microliths' (the finest mesoscopic lenses of till bordered by fracture surfaces), the following subdivision into a coarsely-brecciated till and finely-brecciated till was made (Fig. 3).

The coarsely-brecciated till is characterised by widely spaced fractures which border microliths ranging in size from centimetres to decimetres (Fig. 3A). According to the geometry and the architecture of their spatial arrangement, these fractures correspond to Riedel ( $R$, $\mathrm{R}^{\prime}$ ) shears, P-type structures and C-S type foliations (Włodarski, 2009). Fractures correspond-
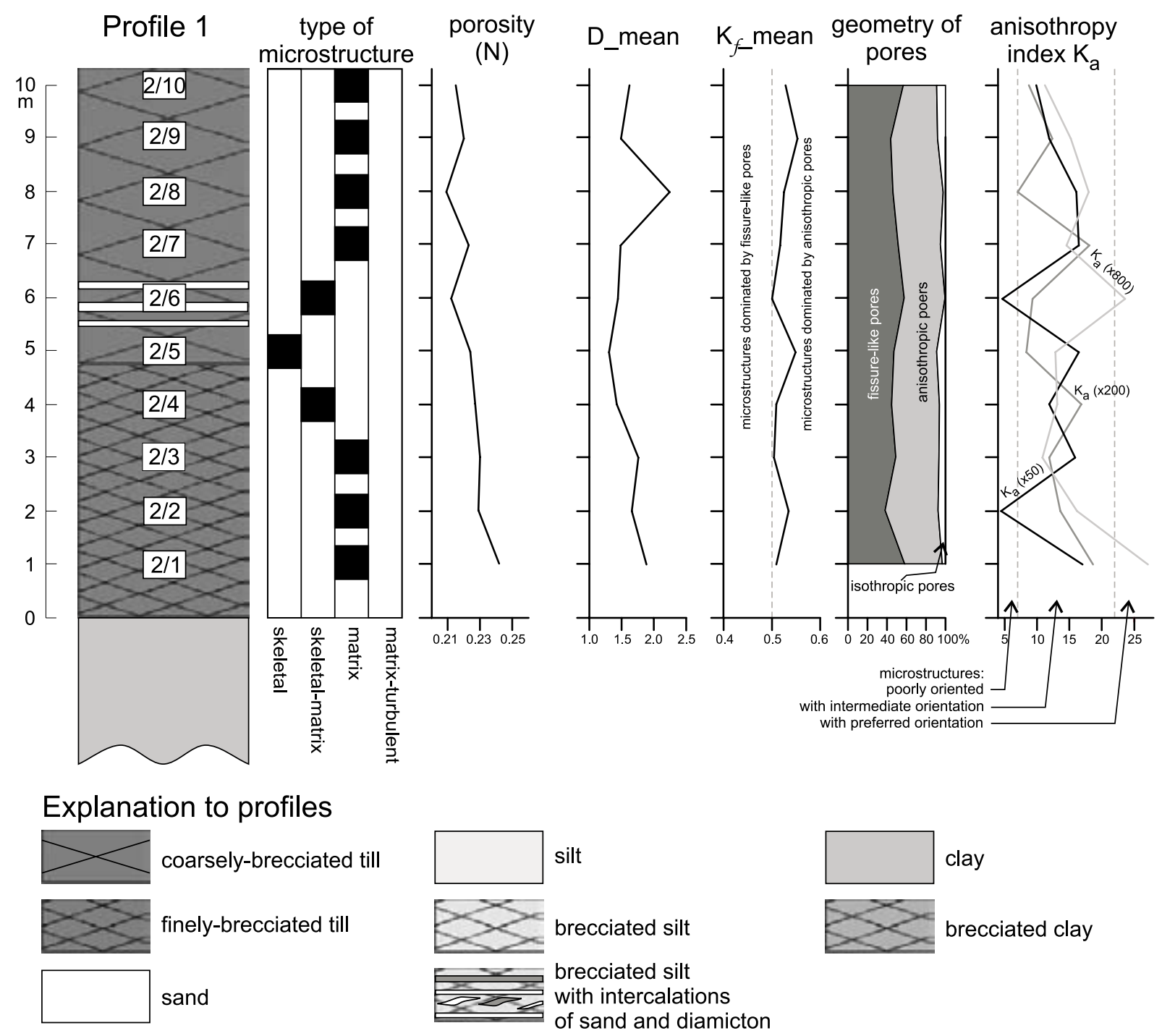

Fig. 4. Sampling locations and results of mesostructural and SEM-based studies in profile 1. 

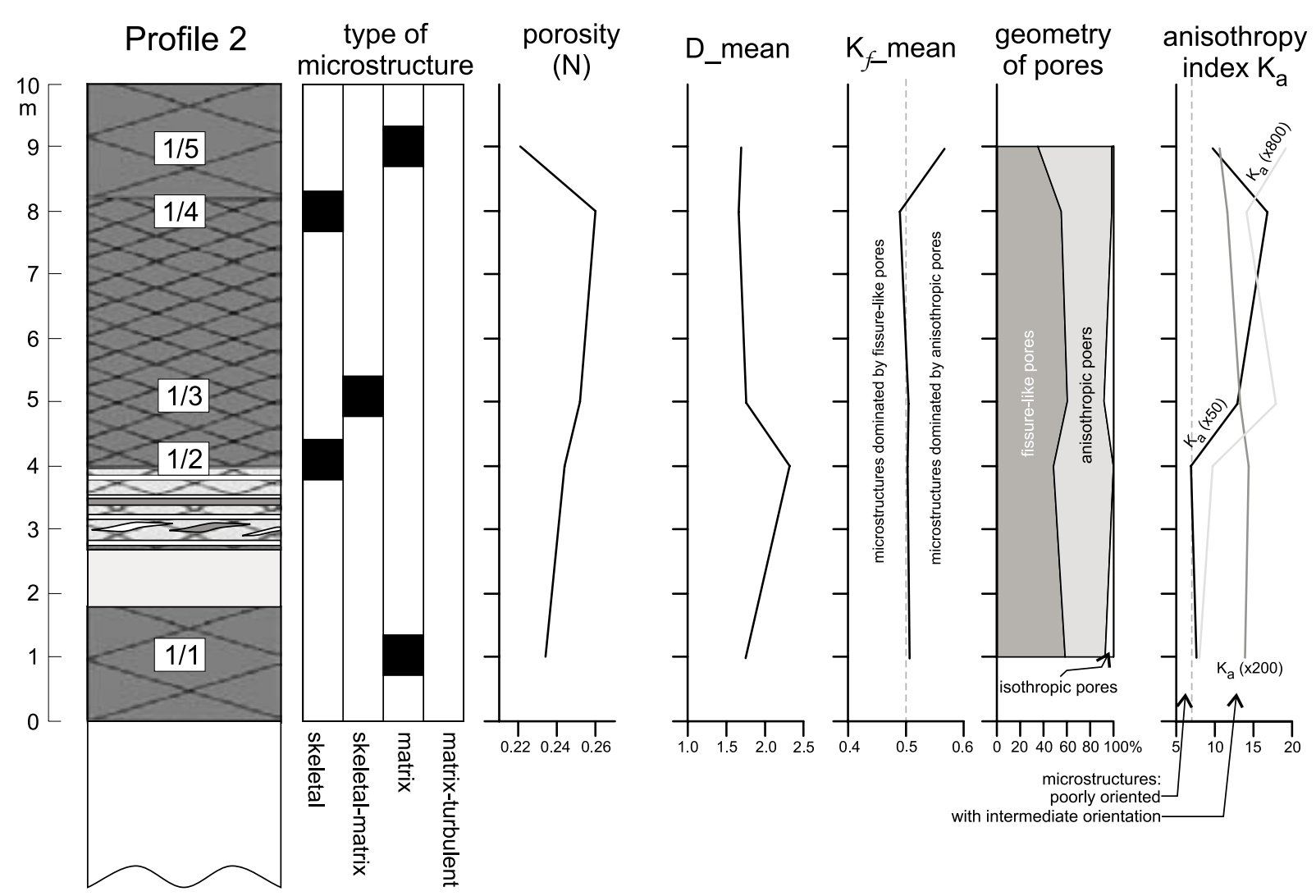

Fig. 5. Sampling locations and results of mesostructural and SEM-based studies in profile 2. See the explanation of lithological and structural symbols in Figure 4.

ing to the R-type or P-type shears represent major surfaces that border other minor shears and thus divide the till into regular sheets.

The finely-brecciated till is characterised by closely spaced fractures that are represented by irregular or anastomosing surfaces (Fig. 3B). The microliths bordered by these surfaces range in size from millimetres to centimetres. It is difficult to recognise whether fractures represent major or minor surfaces.

\section{Microstructural analysis in SEM}

Microstructural SEM studies were carried out on vertical cross-sections of N-S orientated till samples. The N-S orientation was chosen because of the similar direction of advance of the Odranian ice sheet in the study area (Włodarski, 2009). The undisturbed till samples were dried using a freeze-drying method (Trzciński, 1998). The scanning electron microscope was used to obtain images at magnifications of 50x, 200x and 800x.
The qualitative analysis focused on the detailed characteristics of the microstructures according to their classification after GrabowskaOlszewska et al. (1984). The microstructural characteristics of the till were defined in terms of microfabric features, their spatial arrangement and their quantitative interrelationships, according to Collins \& McGown (1974), Grabowska-Olszewska et al. (1984) and Bennett et al. (1991). The following microfabric features were taken into account (Fig. 8, see also the Glossary and the Results section): (1) particles, (2) particle assemblages, and (3) pore space.

The particles are represented by elementary microfabric features that behave physically as an entity under natural geological conditions. Because the clay particles are usually found in an aggregated stage where individual clay platelets (microcrystals of clay minerals) group together into composite units, two types of clay particles were recognised: microaggregates and domains. Additionally, silt or sand particles as well as silt or sand particles clothed in clay particles were defined within this class of 
microfabric features. The particle assemblages are composite units of particle organisation, which consist of one or more types of parti- cles. There are connectors, aggregations, interweaving bunches and matrix. The pore space is represented by voids existing within and
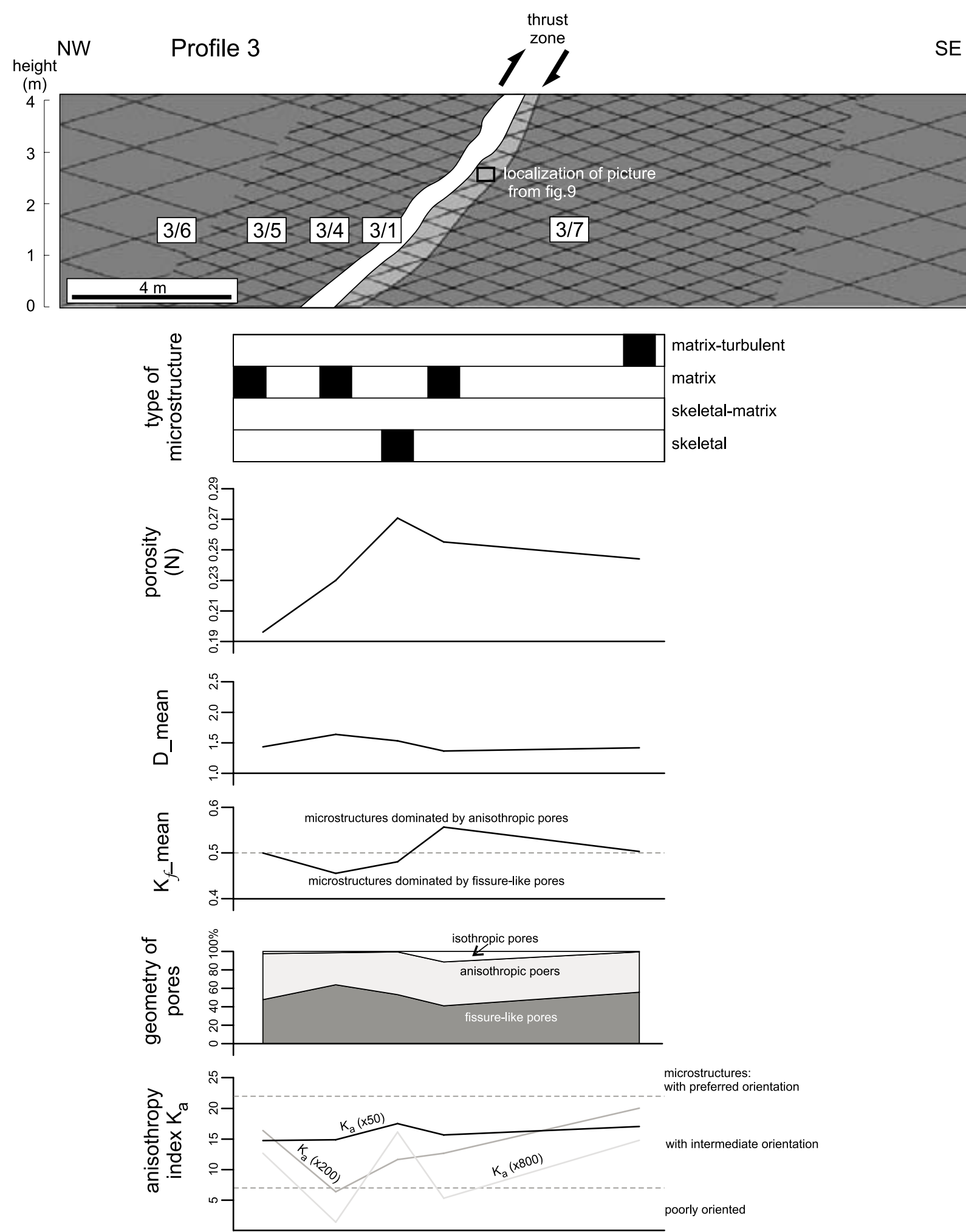

Fig. 6. Sampling locations and results of mesostructural and SEM-based studies in profile 3. See the explanation of lithological and structural symbols in Figure 4. 
between the microfabric features described above, including interparticle and interassemblage pores. Additionally, linear zones with preferred orientation of microfabric features were recognised (Fig. 8).

Digital analysis of SEM images was used to obtain quantitative data on the characteris- tics of the pore spaces. This analysis was performed following the methodology outlined by Trzciński (1998), and using STIMAN (Structural Image Analysis) software version 2.07. The porosity $(\mathrm{N})$, pore diameter $(\mathrm{D})$, form index of the pores $\left(K_{f}\right)$ and anisotropy index of the microstructure $\left(\mathrm{K}_{\mathrm{a}}\right)$ were thus determined.

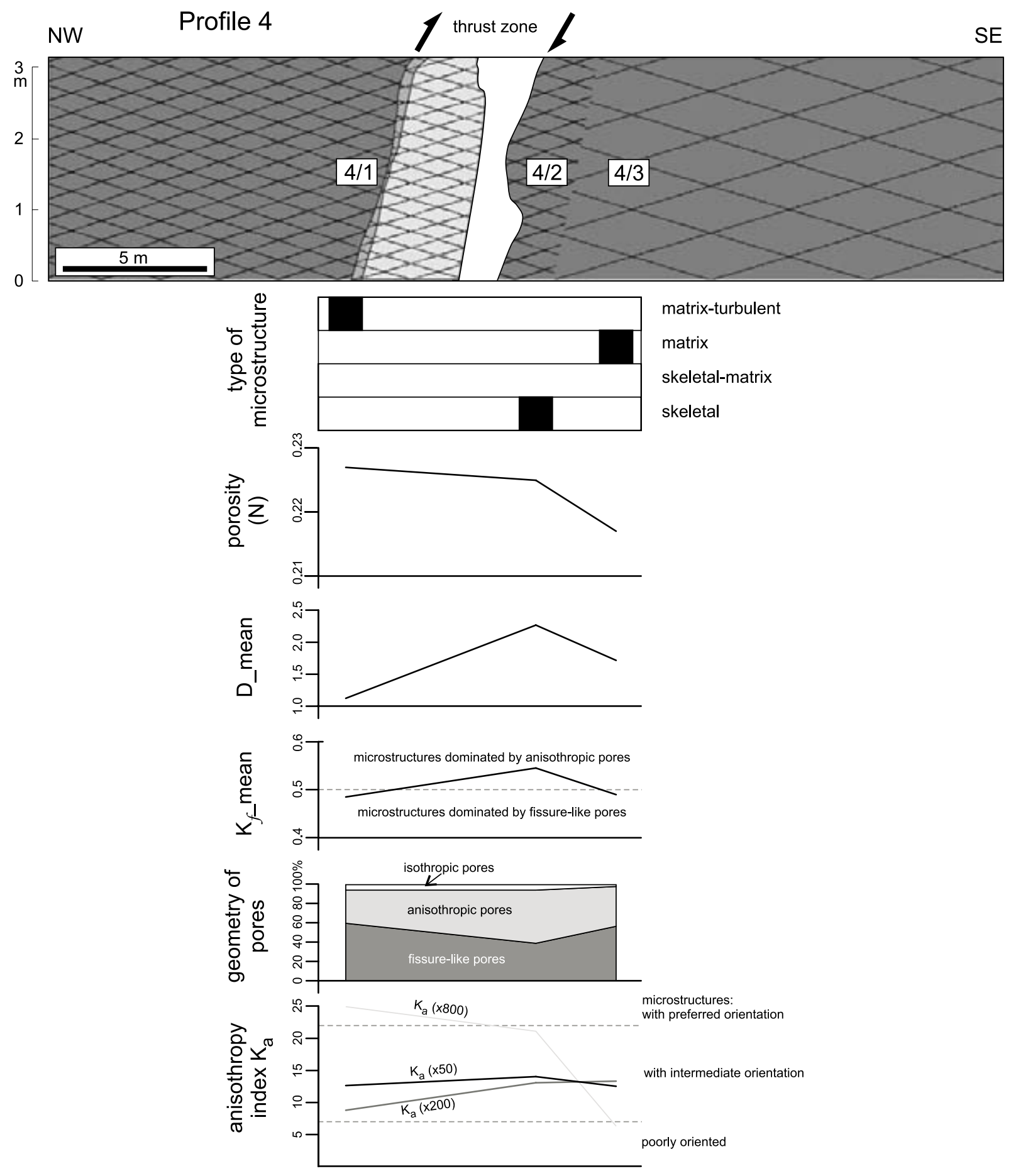

Fig. 7. Sampling locations and results of mesostructural and SEM-based studies in profile 4. See the explanation of lithological and structural symbols in Figure 4. 


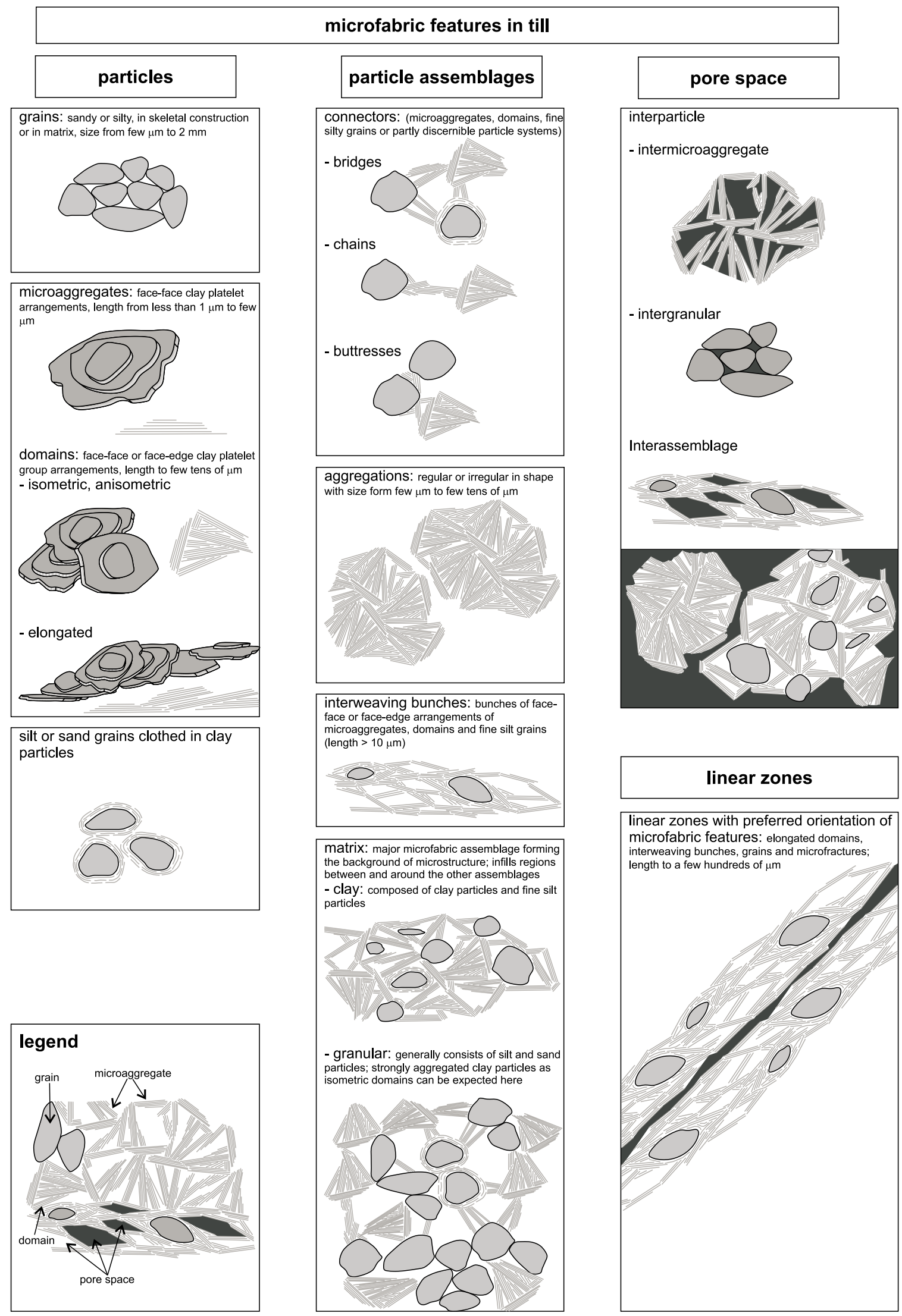

Fig. 8. Synoptic diagram of the terminology used for microfabric features, in perspective and in cross-section views (modified from Collins \& McGown, 1974; Bennett et al., 1991). 
These parameters provided the basis for classification of the pores. According to the pore diameter (D), ultrapores $(<0.1 \mu \mathrm{m})$, micropores $(0.1-10 \mu \mathrm{m})$, mesopores $(10-1000 \mu \mathrm{m})$ and macropores $(>1000 \mu \mathrm{m})$ were distinguished, following Grabowska-Olszewska et al. (1984). Values of the form index of pores $\left(\mathrm{K}_{f}\right)$ allowed distinction between fissure-like pores $\left(\mathrm{K}_{f} \leq\right.$ $0.5)$, anisometric pores $\left(0.5<\mathrm{K}_{f} \leq 0.8\right)$ and isometric pores $\left(0.8<K_{f} \leq 1\right)$, following Trzciński (1998). Using the same criteria, the geometry of microaggregate pores with a diameter of less than $2 \mu \mathrm{m}$ were analysed. Based on values of the anisotropy index of microstructure $\left(\mathrm{K}_{\mathrm{a}}\right)$, poorly oriented microstructures $\left(0<\mathrm{K}_{\mathrm{a}} \leq 7 \%\right)$, microstructures with intermediate orientation $\left(7 \%<\mathrm{K}_{\mathrm{a}} \leq 22 \%\right)$ and microstructures with preferred orientation $\left(22 \%<\mathrm{K}_{\mathrm{a}} \leq 78 \%\right)$ were defined, again following Trzciński (1998). The anisotropy index of microstructures was described separately according to images made at magnifications of 50x, 200x and 800x. The mean values of the pore diameters (D_mean) and the form indexes of pores $\left(\mathrm{K}_{f-}\right.$ mean) were calculated for each sample. Moreover, the percentage of all types of pores was estimated.

Some statistical properties of the pore-space parameters were estimated and then correlated with the density of the mesoscopic fractures. The univariate variance analysis ANOVA and Pearson's correlation analysis were used for the purpose. The statistical significance of both analyses was at the 95\% confidence level using Sheffe's, Leven's and Pearson's tests. The statistical analyses were performed using Statistica version 5.5 software (Statistica, 1998).

\section{Results}

\section{Mesostructural characteristics}

A summary of the results of the mesostructural analysis is presented in Figure 4-7. It appears that both the coarsely-brecciated till and the finely-brecciated till are equally distributed over the whole study area. The contacts between these types of till are gradual, with transitional zone widths ranging from decime- tres to metres. The fracture pattern within the transitional zones is neither irregular as in finely-brecciated till, nor spatially arranged as in coarsely-brecciated till. The frequency of major shear fractures gradually increases towards the coarsely-brecciated till (Fig. 3B).

The finely-brecciated till occurs in two characteristic positions: (1) in the lower part of till strata that are underlain by low-permeability deposits, i.e. silts, clays (Fig. 4) and browncoals (the thickness of finely-brecciated till ranges here from decimetres to metres); (2) at the contact with mesoscopic thrust planes (Figs. 6, 7) (the thickness of the finely-brecciated till ranges here from several metres to a few tens of metres, and differs between the hanging wall and the foot wall of the thrust). For example, the greater thickness of the finely-brecciated till in profile 3 occurs within the foot wall (Fig. 6 ), while it is thicker within the hanging wall in profile 4 (Fig. 7). The observed differences in thickness of the finely-brecciated till are related to the permeability of the deposits incorporated into the thrust zones. In profile 3 , incorporated sand and clay are present in the thrust zone, whereas in profile 4 silt is also present within the thrust zone. In both profiles, these deposits form a succession of thrust-parallel layers. The thickness of the finely-brecciated till thus seems greatest within thrust walls that are in direct contact with layers of low-permeability sediments such as silt and clay.

Coarsely-brecciated till occurs mainly in the upper part of the till strata. However, it also occurs in the lower part of till strata that are underlain by permeable sands of up to a few metres thick (Fig. 5). There is no relationship between the occurrence of the coarsely-brecciated till and the mesoscopic thrusts.

Deposits incorporated into the mesoscopic thrust zones are densely cut by small fractures (Fig. 9) like those observed within the finely-brecciated till (Fig. 3B). Moreover, the geometry of some fractures within clay layers corresponds to C-S foliation, $\mathrm{R}$ shears and $\mathrm{P}$ structures (Figs. 9A, 9B). Such a geometry suggests simple shearing along a plane parallel to the mesoscopic thrust zone. 

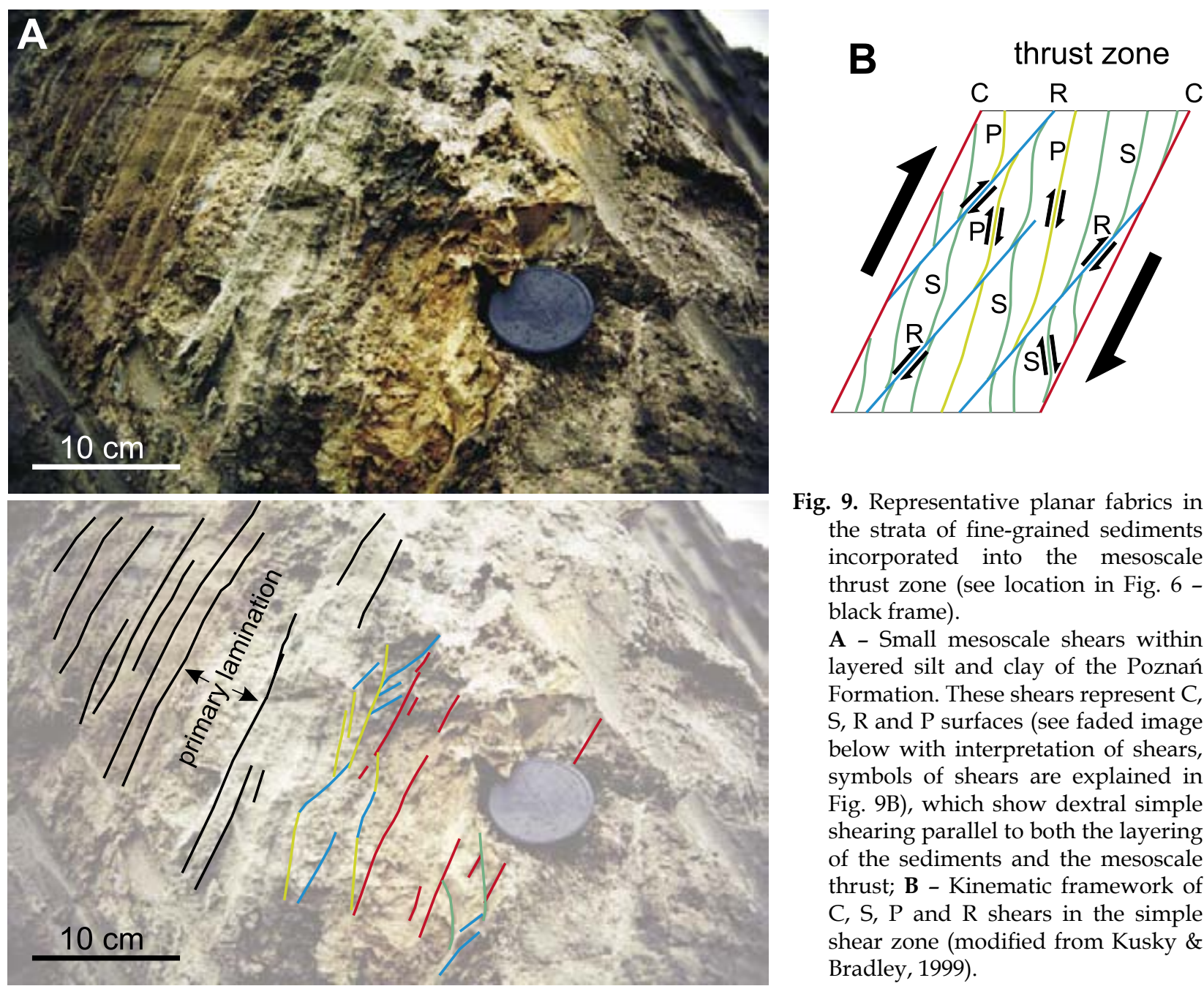

Fig. 9. Representative planar fabrics in the strata of fine-grained sediments incorporated into the mesoscale thrust zone (see location in Fig. 6 black frame).

A - Small mesoscale shears within layered silt and clay of the Poznan Formation. These shears represent $C$, $S, R$ and $P$ surfaces (see faded image below with interpretation of shears, symbols of shears are explained in Fig. 9B), which show dextral simple shearing parallel to both the layering of the sediments and the mesoscale thrust; B - Kinematic framework of C, S, P and R shears in the simple shear zone (modified from Kusky \& Bradley, 1999).

\section{Microstructural characteristics}

Through the qualitative and quantitative SEM analyses of the till samples, four types of microstructures can be distinguished: skeletal, matrix, matrix-skeletal and matrix-turbulent (Figs. 4-7). Additionally, linear zones with preferred orientation of microfabric features can be distinguished in some microstructures.

\section{Skeletal microstructure}

The skeletal microstructure is composed of framework grains and a granular matrix. The framework grains consist of sand or silt grains which generally have a diameter of 100-300 $\mu \mathrm{m}$, in some cases up to $700 \mu \mathrm{m}$ (Fig. 10A). The surfaces of these grains are usually coated with clay particles. The framework grains have no preferred orientation and float in the granular matrix. However, there are some zones where grains form irregular or linear closed frameworks (Fig. 10A, dashed lines). The long axes of the framework grains within such linear structures are often orientated parallel or slightly oblique to the general direction of the structures. Thus, these linear closed frameworks are similar to the lineations or grain stackings described by Menzies et al. (2006). Their maximum length is up to $2000 \mu \mathrm{m}$.

The granular matrix is composed mainly of silt grains and isometric clay domains (Fig. 10B). Individual microaggregates of clay particles are usually combined into higher-order microfabric features such as bridges, buttresses and chains (Fig. 10C). The contacts between microaggregates are of edge-to-edge or edge-to-face type. The same contacts are present between individual microaggregates and other particles of the granular matrix. In some cases, the microaggregates form loosely 

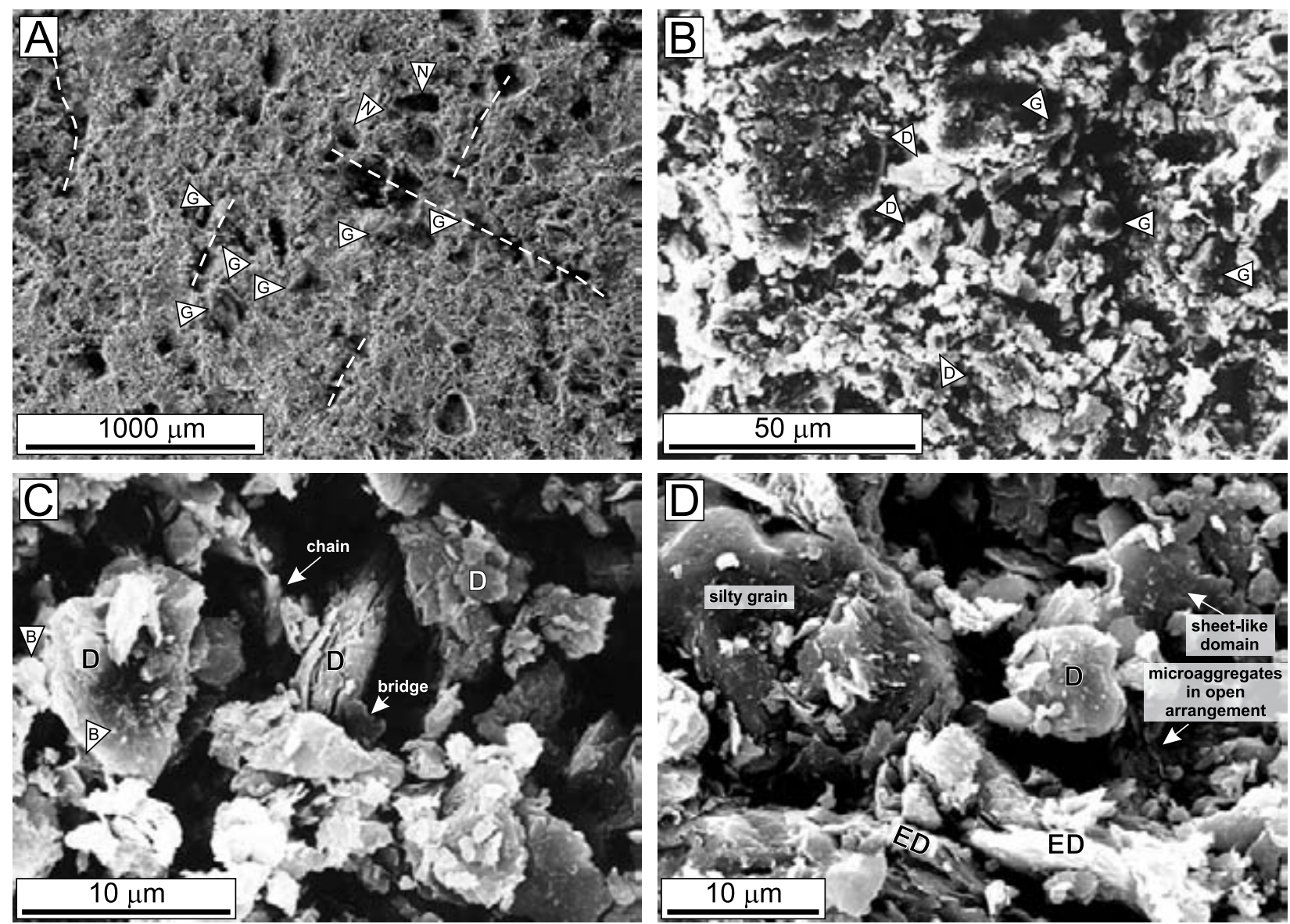

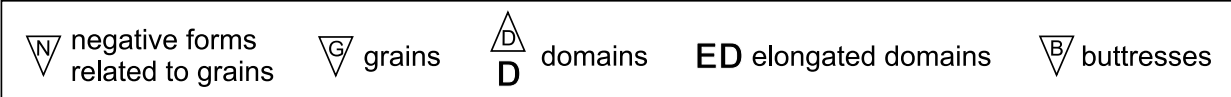

Fig. 10. SEM images of the representative microfabric features within the skeletal microstructure.

A - Sandy and silty grains within tightly packed granular matrix. Note that many grains are represented by negative and rounded features created by grain plucking during preparation of the samples; $\mathbf{B}$ - Granular matrix composed of fine silty grains and isometric domains; $\mathbf{C}$ - Connectors between domains in the granular matrix. Note the edgeto-edge and face-to-edge contacts between microaggregates as dominant type; D - Examples of elongated domains with domination of face-to-face and low angle face-to-edge contacts between the microaggregates.

packed and open arrangements (see the Glossary) (Fig. 10D). Elongated domains of clay microaggregates are rarely present within the skeletal microstructure. They are represented by arrangements of more closely packed and overlapping microaggregates (Fig. 10D). The contacts between the microaggregates are of face-to-face and low-angle face-to-edge types. The maximum length of the elongated domains is up to few tens of micrometres. These domains occur as individual microfabric features and do not form interweaving bunches.

The pore space within a skeletal microstructure is represented mainly by intergranular pores between clay domains (Fig. 10C) and by intermicroaggregate pores (Fig. 10D). Inter- assemblage pores within the granular matrix play a minor role (Fig. 10B). The intergranular pores have an irregular and anisometric shape, and they are often enclosed by connectors. The diameters of the intergranular pores range from $2 \mu \mathrm{m}$ to $10 \mu \mathrm{m}$, and thus these features represent micropores. The intermicroaggregate pores show a wide variety in shape, viz. from irregular to anisometric to fissure-like. Their diameters range from less than $0.1 \mu \mathrm{m}$ (ultrapores) to $2 \mu \mathrm{m}$ (micropores). The total porosity of the till samples, varying between 0.19 and 0.26 , is much lower than the typical values for a skeletal microstructure of clayey sediments (Grabowska-Olszewska et al., 1984). According to the spatial arrangement of pores, 
the skeletal microstructures show a poor to intermediate orientation.

\section{Matrix microstructure}

The matrix microstructure is composed of framework grains and clay matrix. The framework grains are represented by fine- to medium-grained sand and medium- to coarsegrained silt. The framework grains form locally an irregular or linear closed framework (Fig. 11A).

The clay matrix consists of microaggregates and their domains. The fine-grained silty grains play a minor role. The microaggregates tend to form mainly densely packed and poorly oriented arrangements, where edge-to-edge and edge-to-face contacts dominate (Fig. 11B). There are, obviously, loosely packed and open arrangements of individual microaggregates.

The microaggregates are isometric and elongated (Fig. 11B). They have face-to-face and low-angle face-to-edge contacts. The elongated domains are often combined into higher-order microfabric features such as interweaving bunches (Fig. 11C). In some cases, fine-grained silt grains are present. Within the interweaving bunches, the microaggregates form densely packed, preferentially orientated turbostratic
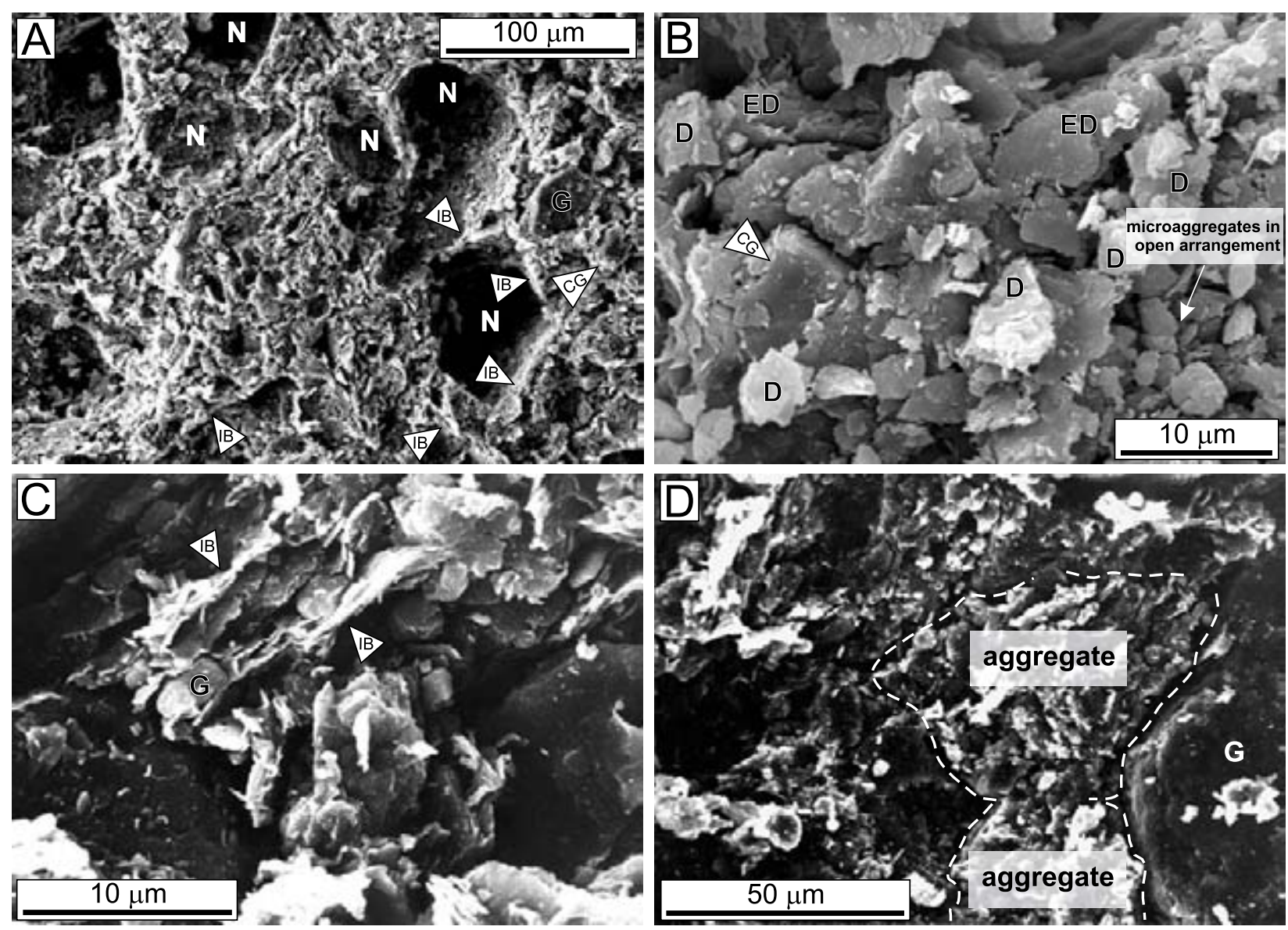

$\mathbb{N}$ negative forms $\quad A$ grains $C G$ grains clothed

related to grains $\quad G$ grains $\quad \mathrm{G}$ in clay particles

D domains ED elongated domains $\sqrt{\mathbb{B}}$ interweaving bunches

Fig. 11. SEM images of the representative microfabric features within the matrix microstructure.

A - Sandy and silty grains within a clay matrix. Some grains are coated by clay particles. Note the interweaving bunches which delineate negative and rounded features related to the grains; $\mathbf{B}$ - Particles and their arrangement within a clay matrix. The contacts between the microaggregates are edge-to-edge and face-to-edge; C - Interweaving bunches composed of elongated domains, micoaggregates and fine silty grains. Note the turbostratic arrangement of microaggregates with predominance of face-to-face and low angle face-to-edge contacts; D - Examples of isometric aggregates with more tightly packed microaggregates. Note the fissure-like interassemblage macropores between the aggregates and silty grains. 
arrangements (see the Glossary). Their maximum length ranges from some tens to several hundreds of micrometres. Their width ranges from 1 to $3 \mu \mathrm{m}$. The interweaving bunches often display an anastomosing pattern around the large fragments of clay matrix and silt or sand grains (Fig. 11A).

Within the clay matrix, regular and irregular clay aggregations are present. Regular aggregations dominate; they are composed of densely packed and poorly oriented arrangements of microaggregates and fine-grained silt grains (Fig. 11D). The concentration of these particles is higher than in the clay matrix.

The pore space within the matrix microstructure is formed mainly by small intermicro-aggregate pores (Fig. 11B). Intergranular pores and interassemblage pores play a minor role (Fig. 11D). Where the individual microaggregates are loosely packed and form open arrangements, the intermicroaggregate pores are isometric, with sizes up to $10 \mu \mathrm{m}$. In other cases, anisometric or fissure-like pores dominate, and their maximum sizes range from 1 to $2 \mu \mathrm{m}$. The total porosity of the till samples varies between 0.19 and 0.29 , thus being lower than the typical values mentioned by Grabowska-Olszewska et al. (1984) for the matrix microstructure of clayey deposits. The matrix microstructure shows an intermediate orientation.

\section{Matrix-skeletal microstructure}

The matrix-skeletal microstructure occurs in both the finely-brecciated till (four samples collected from profiles, see Figs. 4, 5) and the coarsely- brecciated till (two samples collected from isolated sites of till strata). The presence of a mixed granular-clay matrix provides a basis for subdividing this type of microstructure. The relative proportions of clay particles and fine silt grains within the matrix are higher than in the granular matrix of the skeletal microstructure (Fig. 12A). Many of the clay particles form coating of silt grains. The clay particles commonly form microaggregates and isometric domains that are not densely packed (as in the clay matrix) (Fig. 12B). The microaggregates and domains have predominantly edge-toedge and face-to-face contacts; the latter appear to occur only locally within a few examples of elongated domains. Some individual microaggregates and isometric domains are combined into higher-order microfabric features such as buttresses and bridges (Fig. 12B).

The pore space within the matrix-skeletal microstructure consists mainly of intergranular and intermicroaggregate pores (Figs. 12A, 12B). The intergranular pores show a wide variety of shapes, from irregular and anisotropic to more regular elongated or fissure-like. They are mainly mesopores. The intermicroaggregate pores have irregular shapes, and are typically micro- and ultrapores (diameters range from less than $0.1 \mu \mathrm{m}$ to a few micrometres). The total porosity within the granular-clay matrix ranges from 0.22 to 0.27 . The matrixskeletal microstructure shows, as a rule, a intermediate orientation; a preferred orientation is present occasionally.

\section{Matrix-turbulent microstructure}

The matrix-turbulent microstructure was observed only within the finely-brecciated till (Figs. 6-7). The clay matrix is characterised by more clay particles than fine-grained silt grains (Fig. 12C). Clay particles form mainly elongated domains and microaggregates. These particles often form higher-order microfabric features such as interweaving bunches (Fig. 12D). Some grains of fine silt are present. Within interweaving bunches, the microaggregates and elongated domains form densely packed welloriented turbostratic arrangements. The microaggregates and domains have mainly face-toface and low-angle face-to-edge contacts. The maximum length of interweaving bunches is 100-200 $\mu \mathrm{m}$ (Figs. 12C, 12D), and their average width is several micrometres.

Because of the predominance of individual clay particles in densely packed turbostratic arrangements, the pores are mainly represented by fissure-like intermicroaggregate and interassemblage subtypes. The interassemblage pores usually occur between individual interweaving bunches, and between interweaving bunches and the clay matrix (Fig. 12D). The width of the interassemblage pores ranges from a few to $10 \mu \mathrm{m}$. The intermicroaggregate pores have submicrometre widths. The total porosity calculated reaches values between 0.23 and 

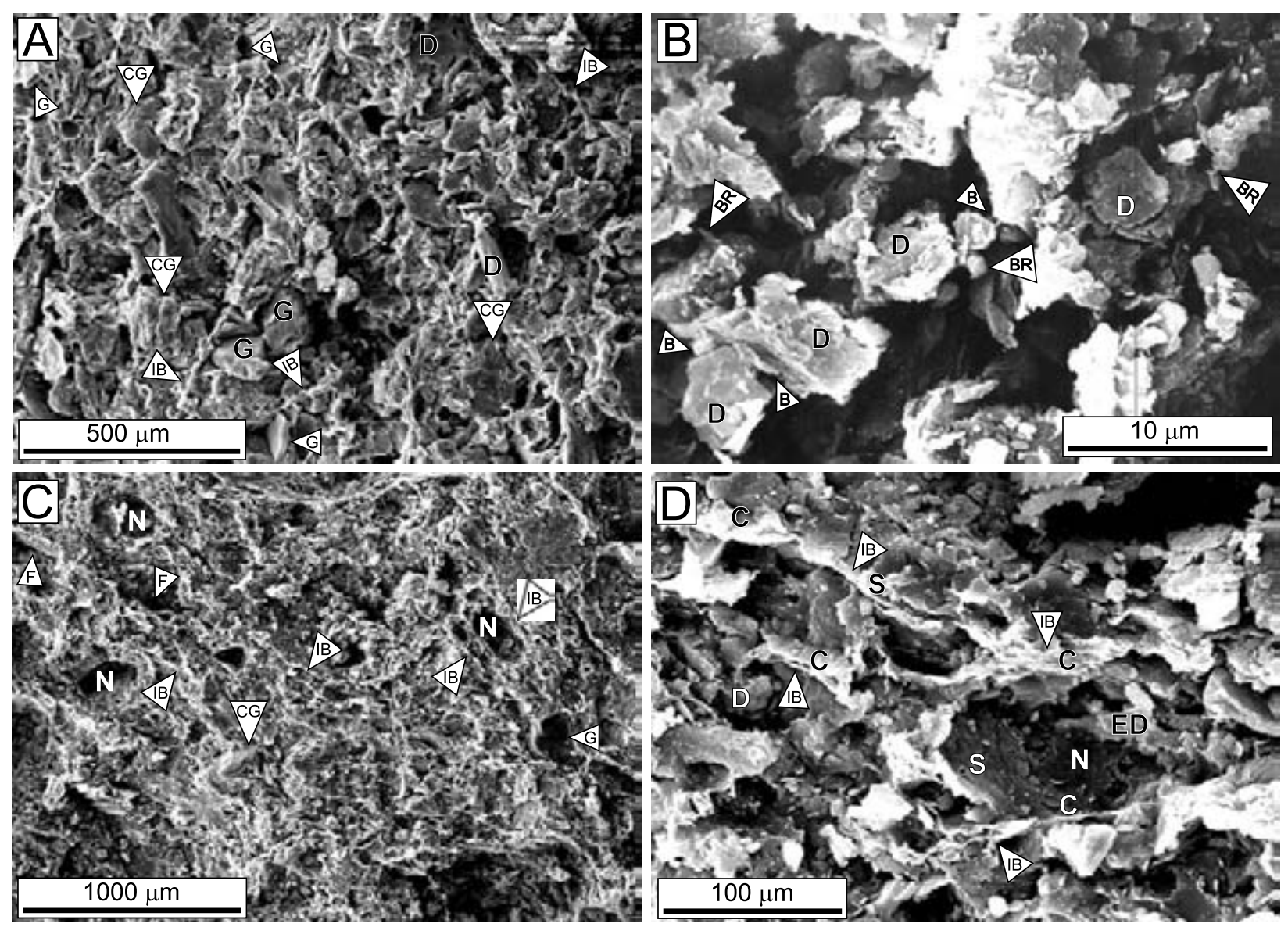

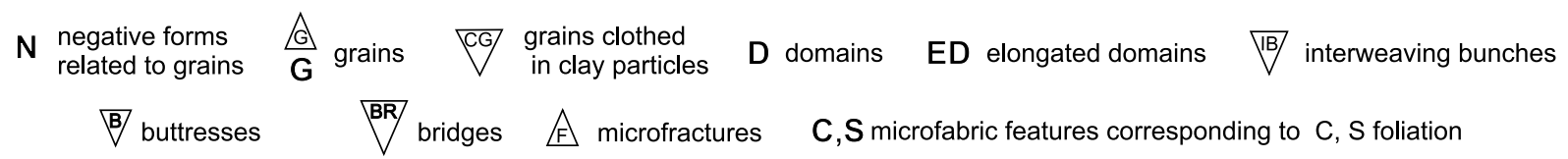

Fig. 12. SEM images of the representative microfabric features within the transient microstructures: matrix-skeletal and matrix-turbulent.

A - Clay-granular matrix composed of grains, grains clothed in clay particles and domains. Note the linear zones where interweaving bunches dominate; B - Isometric domains and connectors within a clay-granular matrix. Between microaggregates and domains, the edge-to-edge and face-to-face contacts predominate; C - Clay matrix with strongly preferred orientation of clay particles in a matrix-turbulent microstructure. Note the many interweaving bunches which form narrow linear features. Some of bunches form, together with microfractures and grains, linear zones with a preferred orientation of microfabric features; D - Internal morphology of interweaving bunches. The face-to-face and low angle face-to-edge contacts predominate.

0.25. The microstructure shows mainly an intermediate orientation, but locally a preferred orientation is present within the interweaving bunches.

\section{Linear zones with preferred orientation of microfabric features}

In some cases, the microfabric has linear zones in which features show a preferential arrangement, formed by elongated domains, interweaving bunches and microfractures. The components forming one of these features are preferentially orientated (sub)parallel to each other (Figs. 12C, 12D). The width of the linear zones ranges from a few to several tens of micrometres. The maximum length of the linear zones is up to a few millimetres. It is important to note that the general directions of the various linear zones are often the same as the orientation of the long axes of the silt and sand grains in the matrix (Figs. 12C, 12D). The linear zones occur within all types of microstructures, ex- 


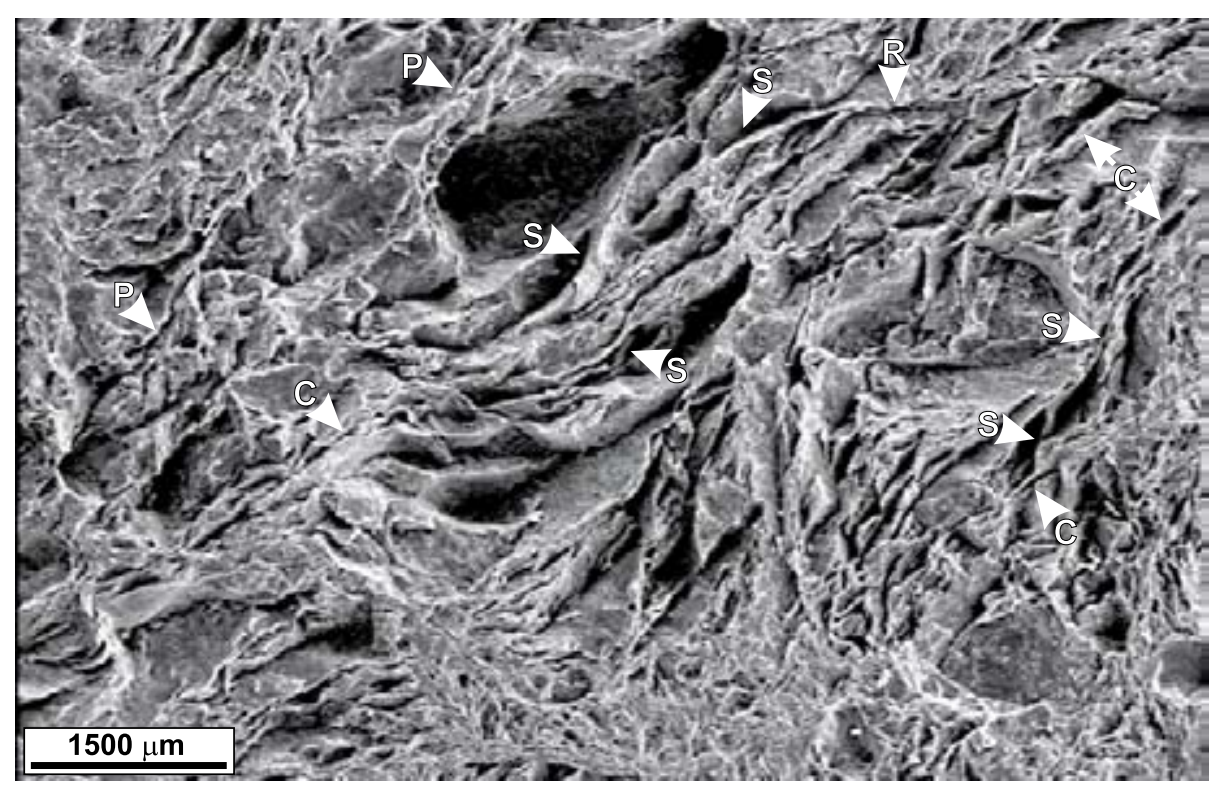

Fig. 13. SEM-image of microscale shears within a thrusted clay layer of the Poznań Formation (see localition in Fig. 6). Note that the geometry and the slip sense of the shears is the same as shown in Figure 9 .

cept the skeletal microstructure. They are most frequent in the matrix-turbulent microstructure and relatively rare in the matrix-skeletal microstructure.

The linear zones display anastomosing patterns that correspond partially to the C-S type foliation (Fig. 12D). The occurrence of silt and sand grains within the matrix causes that the C-S like pattern of the linear zones is weakly developed in comparison to examples of the clay-rich matrix (cf. Vannucchi et al., 2003). Such a clay-rich matrix is present in a clay layer that has become tectonically incorporated into the mesoscopic thrust zone shown in Figures 9 and 13 . The clay particles form densely packed turbostratic arrangements that are the major component of the matrix, but that also form interweaving bunches. The C-S geometry of the linear zones suggests simple shearing along planes parallel to the mesoscopic thrust. The kinematics are similar to that indicated previously on the basis of the mesoscopic shears cutting the clay layer (Fig. 9).

\section{Statistics of microfabric features}

Quantitative analysis performed on SEMbased images of the till samples shows some statistically significant relationships between the types of microstructure, some pore-space parameters, and the mesoscopic type of the till (Fig. 14). The statistical significance is summarised in Figure 14A. Histograms showing the frequency of microstructure types in the coarsely-brecciated and in the finely-brecciated tills (Fig. 14B) reveal a similar distribution of matrix and skeletal microstructures within both types of till, but transitional microstructures (skeletal-matrix and matrix-turbulent) dominate only in the finely-brecciated till. The frequency of pores is higher in the finely-brecciated till than in the coarsely-brecciated till (Fig. 14C). Analysis of the mean values of the form indexes of the pores $\left(\mathrm{K}_{f}\right)$ shows that anisometric pores dominate in the coarsely-brecciated till, whereas a high content of fissure-like pores are present in the finely-brecciated till (Fig. 14D). The values of the anisotropy indexes of the microstructure $\left(\mathrm{K}_{\mathrm{a}}\right)$, as obtained from the SEM-based images at a 200x magnification, are also related to the mesoscopic types of till (Fig. $14 \mathrm{E})$. Pores with an intermediate degree of preferred orientation dominate in all till samples, but a higher anisotropy and thus a more preferred orientation of microfabric features occurs in the finely-brecciated till.

Statistically significant correlations exist between some parameters of the pore space (Fig. 15). The porosity and the anisotropy index of microstructures, as determined from SEM-based images at a 50x magnification $\left(\mathrm{K}_{\mathrm{a}} \times 50\right)$ are strongly correlated (Fig. 15A). Such a strong correlation is also present be- 
A

\begin{tabular}{|l|l|l|l|}
\hline \multicolumn{4}{|l|}{ categorizing factor: mesostructural type of till } \\
\hline parameter & $\begin{array}{l}\text { result of Sheffe's } \\
\text { range test }\end{array}$ & $\begin{array}{l}\text { test of } \\
\text { normality }\end{array}$ & $\begin{array}{l}\text { result of } \\
\text { Levene's test }\end{array}$ \\
\hline porosity & $\mathbf{0 . 0 4 2}$ & + & $\mathbf{0 . 1 6}$ \\
\hline $\begin{array}{l}\text { average diameter of } \\
\text { pores } D \text { mean }\end{array}$ & 0.11 & + & 0.32 \\
\hline $\begin{array}{l}\text { average form index } \\
\text { of pores } K_{f} \text { mean }\end{array}$ & $\mathbf{0 . 0 7 4}$ & + & $\mathbf{0 . 9}$ \\
\hline $\begin{array}{l}\text { content of fissure-like } \\
\text { pores [\%] }\end{array}$ & 0.44 & + & 0.82 \\
\hline $\begin{array}{l}\text { content of pores with } \\
\text { diameter }<2 \mu \mathrm{m}[\%]\end{array}$ & 0.72 & + & 0.60 \\
\hline $\begin{array}{l}\text { content of fissure-like } \\
\text { mesopores [\%] }\end{array}$ & 0.64 & + & 0.85 \\
\hline $\begin{array}{l}\text { content of fissure-like } \\
\text { pores with diameter } \\
<2 \mu \mathrm{m}[\%]\end{array}$ & 0.86 & + & 0.22 \\
\hline$K_{a} \times 50$ & 0.37 & - & 0.17 \\
\hline$K_{a} \times 200$ & $\mathbf{0 . 0 9}$ & + & $\mathbf{0 . 2 6}$ \\
\hline$K_{a} \times 800$ & 0.97 & + & 0.59 \\
\hline
\end{tabular}

B

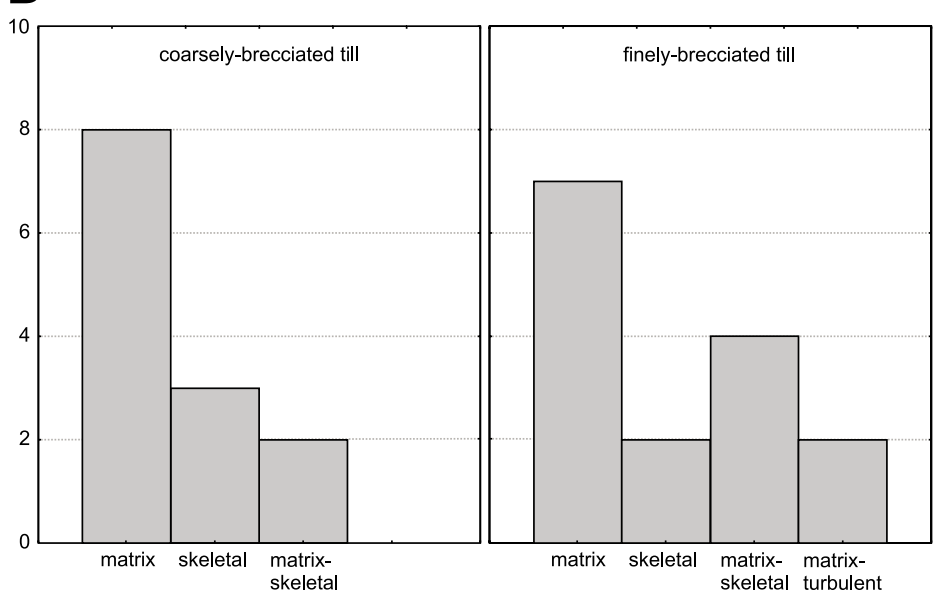

C

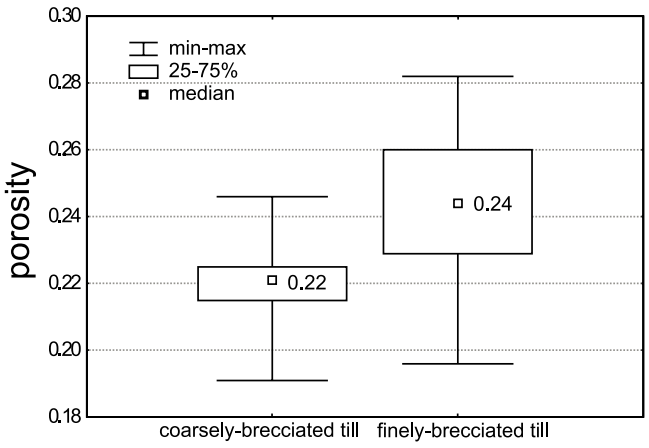

$\mathrm{D}$

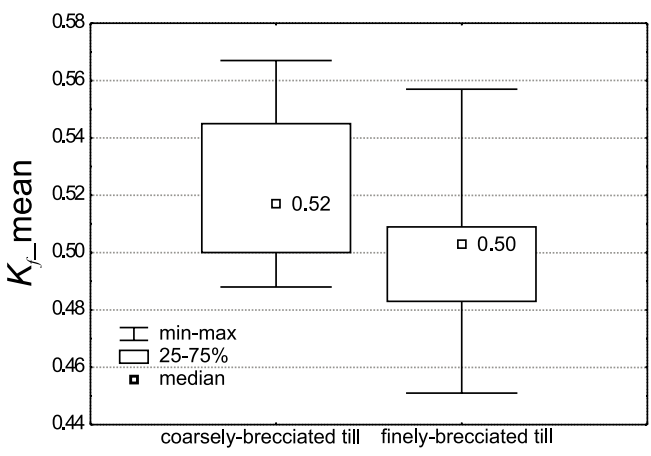

E

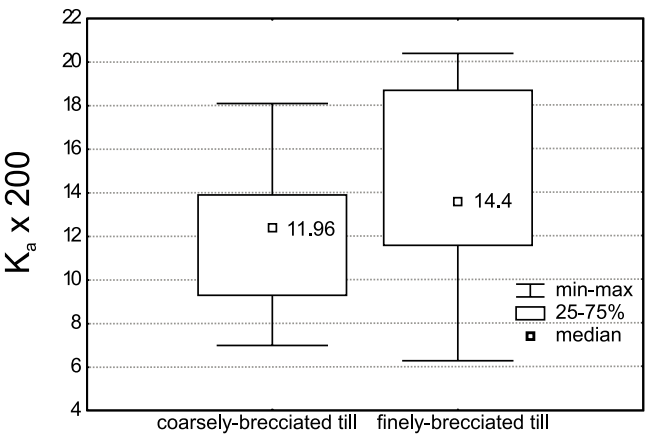

Fig. 14. Primary statistics and ANOVA results.

A - General results of the Scheffe, Levene and normality tests used in the variance analysis. The bolded values of the Scheffe and Levene tests show the statistically significant differences between qualitative microfabric parameters in relation to the mesostructural type of till; $\mathbf{B}$ - Frequency of the distinguished types of microstructure for the coarsely-brecciated and the finely-brecciated tills; C - Median, inter-quartile interval and range of porosity of the mesostructural types of till; D - Median, inter-quartile interval and range distribution relating to the mean values of the form indexes of pores ( $\mathrm{K}_{f-}$ mean) in two mesostructural types of till; $\mathbf{E}$ - Median, inter-quartile interval and range values of the anisotropy indexes of microstructures obtained from the SEM-based images at a 200x magnification $\left(\mathrm{K}_{\mathrm{a}} \times 200\right)$ in relation to the mesostructural types of till.

tween the percentage of fissure-like pores and that of ultra- and micropores (with diameters of less than $2 \mu \mathrm{m}$ ) (Fig. 15B). Two relationships show a mediumpositive correlation; the first one is between the percentage of fissure-like pores and the anisotropy index of microstructure as determined from SEM-based images at a 50x magnification $\left(\mathrm{K}_{\mathrm{a}} \times 50\right)$ (Fig. 15C), and the second one is between the porosity and the percentage of fissure-like pores (Fig. 15D). Additionally, two cases of strongly negative correlation have been found. The first one concerns the mean values of the form indexes of pores $\left(\mathrm{K}_{f-}\right.$ mean) versus the percentage of fissure-like pores (Fig. 15E); the second one exists between the mean values of the pore diameter 

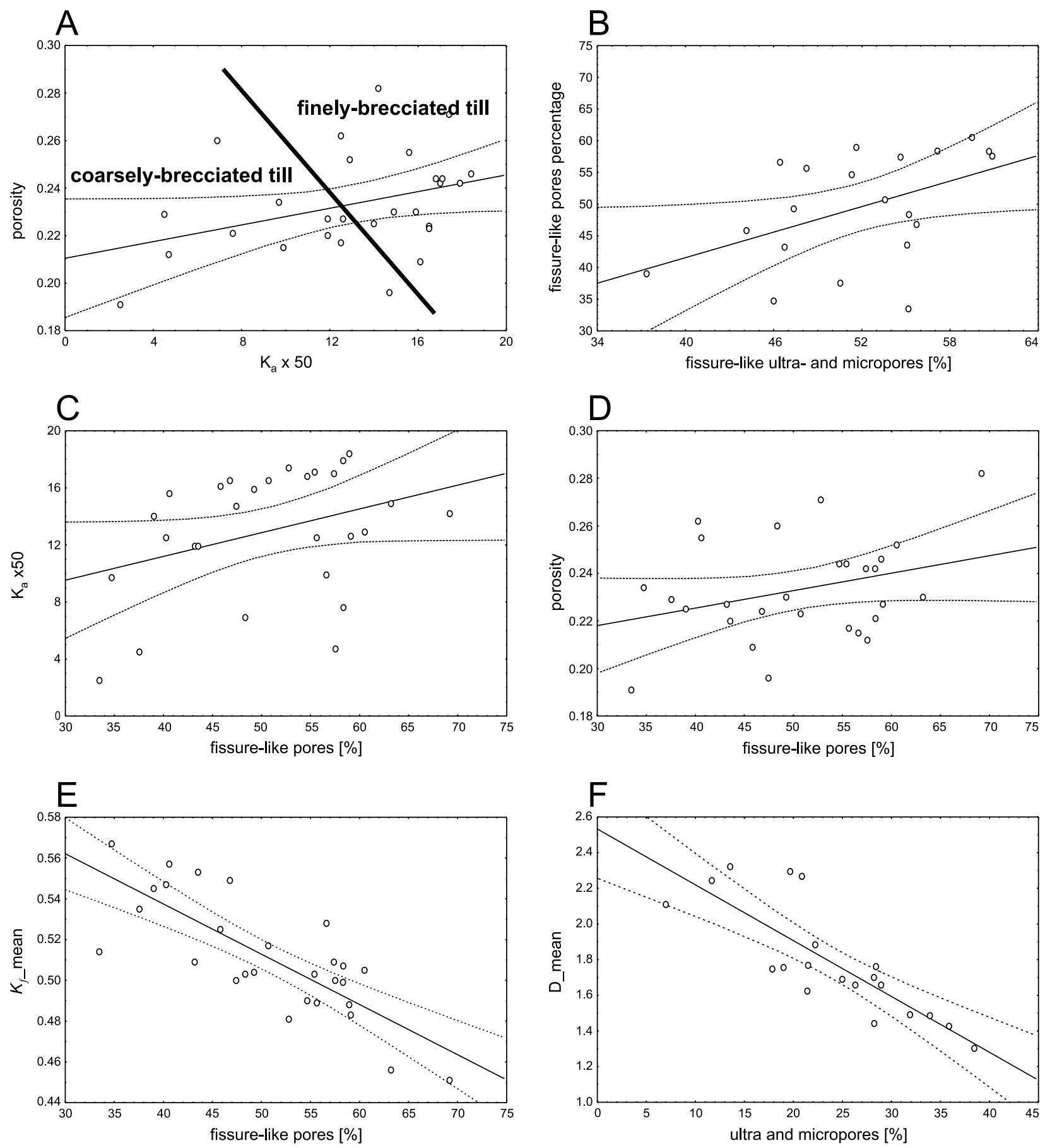

Fig. 15. Scatter diagrams showing results of regression analysis between some pore-space parameters. A significance level of $95 \%$ was used in the statistical tests. See the text for a more detailed explanation.

(D_mean) and the percentage of ultra- and micropores (Fig. 15F).

Only one case of correlation is additionally influenced by a factor related to the mesoscopic type of till. This is the strong positive correlation between the porosity and the anisotropy index of microstructure $\left(\mathrm{K}_{\mathrm{a}} \times 50\right)$ (Fig. 15A). Such a correlation shows that the high poros- ity and the distinctly preferred orientation of pores is typical of the finely-brecciated till.

\section{Discussion}

The different densities of mesoscopic fractures in the till allow two mesoscopic types to 
be distinguished: coarsely-brecciated till and finely-brecciated till. The fracture density is reflected by the microstructure of the till, i.e. it is closely related to the porosity, to the mean values of the form indexes of the pores ( $\mathrm{K}_{f-}$ mean), and to the values of the anisotropy index of the microstructure $\left(\mathrm{K}_{\mathrm{a}}\right)$ as obtained from SEM images at a 200x magnification. The finely-brecciated till, cut by mesoscopic closely spaced fractures, is characterised by a higher porosity than the coarsely-brecciated till. Moreover, anisotropic and fissure-like pores with a relatively well developed orientation dominate in this type of till. In contrast, the coarsely-brecciated till is cut by widely spaced mesoscopic fractures, and the anisometric pores are commonly less well orientated, while the porosity is lower than in the finely-brecciated till.

These relationships are important in the light of the spatial distribution of the finelybrecciated till. This till occurs in the lower part of the till unit that is underlain by low-permeability deposits, and particularly in the contact zone with mesoscopic thrusts. According to the fault-zone architecture as described by Caine et al. (1996), a fault core and a damage zone are distinguished. The fault core is represented by the lithological and structural unit along which most fault movement took place.

Within poorly indurated sediments such as the till under study, the fault core may be absent or poorly developed as narrow, discrete and discontinuous slip surfaces (Caine et al., 1996). The damage zone, in turn, is characterised by minor shears and joints cutting the fault walls of the rocks involved. The width of the damage zone varies, depending on the shearstrain magnitude and the hydraulic conditions during faulting. The density of the fractures within the damage zone evidently increases towards the fault core. According to the model of fault-zone architecture by Caine et al. (1996), the position of the finely-brecciated till can be related to the damage zones along mesoscopic thrusts (Fig. 16). Moreover, the development of densely spaced fractures could be controlled by the occurrence of low-permeability deposits incorporated into the thrust zone. These deposits might act as a barrier for pore-water expulsion from the damage zone into the fault core and then out of the system, thus causing undrained deformation under closed hydraulic conditions (Fig. 16). The high pore-water content could be maintained here longer than in other parts of the till outside of the contact zone with the mesoscopic thrusts. There is an experimentally verified positive relationship between the water content and the strain magnitude manifested by the development of wide zones (up to $10 \mathrm{~mm}$ across) of densely-spaced shears at the microscale (Arch et al., 1988).

This relationship was extrapolated to a larger scale, including shear zones up to few metres in width (Lash, 1989). Moreover, Lash (1989) proposed a model that describes the relationships between the hydraulic conditions of deformed deposits and the degree of shear strains at this larger scale. According to this model, a progressive development of a wide zone of densely-spaced shears within unconsolidated and pore-water-saturated overpressurized deposits (closed hydraulic conditions) is governed by the expulsion of excess porewater controlled by shear strain. During shear strain within an initially narrow shear zone, the individual shears propagate up to a critical stage of dewatering and strain hardening. At this stage, the increased shear strength causes slip arrest within the initial shear zone. As the strength of the deposit within this initial shear zone becomes higher than that of adjacent, less deformed deposits, shear development can propagate outwards into less deformed, weaker deposits (with a higher pore-water content and pressure), leading to widening of the shear zone. It is important that the more favourable conditions for shear strains can be maintained longer in low-permeability deposits than in high-permeability deposits, and thus the development of wide shear zones is more likely to occur in low-permeability deposits.

The model showing the development of wide zones of densely-spaced shears proposed by Lash (1989) can also be applied to other occurrences of the finely-brecciated till, viz. in the lower part of the till unit that is underlain by low-permeability deposits (Fig. 16). The finelybrecciated till in this position can represent a deposit that was strongly deformed due to (sub)horizontal simple shearing along the con- 

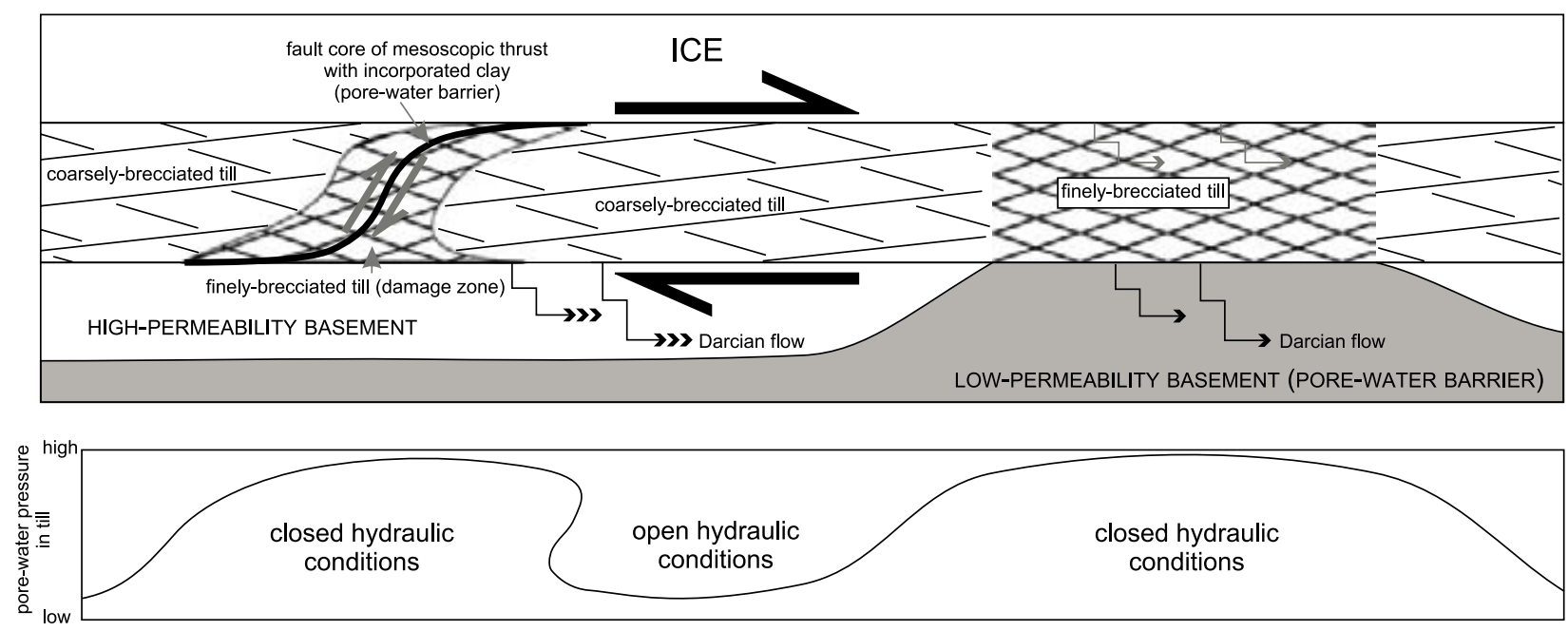

Fig. 16. Influence of subglacial hydraulic conditions on the development of the coarsely-brecciated and finely-brecciated tills. See the text for a more detailed explanation.

tact between active ice and the till. Because of the low permeability of the till substratum (silts and clays), closed hydraulic conditions can be expected within the subglacial zone. The expulsion of excess pore-water, produced during shear strain of the till and governed by Darcy's law, will consequently be limited there. Therefore, the stage of overpressurizing of the deformed till with low shear-strength values was maintained long enough to produce a wide zone of densely-spaced shears, up to several metres. For comparison, open hydraulic conditions can be expected to exist within the subglacial zone where a high-permeability sandy substratum underlies the till, which is represented by coarsely-brecciated till (Fig. 16). Because of the high hydraulic conductivity of the substratum, the expulsion of excess pore-water produced during shear strains was likely more enhanced, and thus a stage of relative underpressurizing of deformed till with consequent high shear-strength values dominated during deformation.

The shear strain of the till resulted not only in mesoscopic shears and fractures, but also influenced the microfabric features observed with SEM. This influence is expressed in two ways. In the first place, linear zones developed in which the microfabric features show a preferred orientation. Their geometry can be considered as a weakly developed C-S type foliation (cf. Vannucchi et al., 2003) because of the high content of silt and sand grains within the clay matrix. The highest density of these linear zones in matrix-turbulent microstructures in finely-brecciated till suggests that the larger discrete shear strains present at a mesoscale occur at a microscale as well. Secondly, there is a significant change in pore space within the matrix. The main changes involve a reorientation of pores and their elongation, and porosity. It is important to note that these changes concern mainly the intermicroaggregate pores of less than $2 \mu \mathrm{m}$, which represent major microfabric features of the matrix. In some cases, the change in pore space is accompanied by preferential reorientation of clay microaggregates that are usually combined in higher-order microfabric features such as elongated domains and interweaving bunches.

These changes of the microfabric features in the matrix show that the shear strains of the till were not only localised in the narrow linear zones but were more pervasive in nature. Obviously, such a dispersion of the shear strain reflects the high content of silt and sand grains within the clay matrix. The influence of the granular composition of deposits on the strain pattern has been studied experimentally (Maltman, 1987; Murray \& Dowdeswell, 1992). These studies report the development of less intense and less localised shear strains as the average particle size of the sediment increases. The individual shear zones produced then 
are characterised by a high spatial dispersion, with widths up to several milimetres, preferential alignment of clay and silt particles, and increasing porosity.

These features have been used by Murray \& Dowdeswell (1992) for assessing the mechanism of subglacial till deformation in terms of synsedimentary compression and simple shearing. These authors also suggest that there is a positive relationship between the porewater content and the degree of preferential arrangement of clay and silt particles within experimentally developed shear zones. It is assumed that such an arrangement results from movement, sliding and rotation of particles with respect to each other to align in a subparallel way with the direction of the principal extensional strain produced by simple shearing. The high pore-water content and closed hydraulic conditions within shear zones cause a reduction of the normal effective stresses acting across the contacts between clay and silt particles (Borradaile, 1981). Taking into account the hydraulic conductivity, the straincontrolled pore-water expulsion within the shear zones with preferentially oriented particles can be more enhanced than in other parts of the matrix. Thus the shear zones can act as pathways for pore-water expulsion. A positive feedback system can be expected in the case of such localised pathways of pore-water flow within overpressurized subglacially deformed sediment (Murray \& Dowdeswell, 1992).

During deformation, the pore-water can be retained along developing shear zones, causing both an increase of the water content and softening of the sediment. A stronger and longer-lasting stage of sediment deformation is then to be expected. It is obvious that the preferential pore-water flow through these shear zones may also result from an increase in porosity and permeability. It has been suggested that an increase in porosity can be related to the positive volumetric strains that cause dilatation and removal of the finest particles by expelled pore-water within developing shear zones. According to the above-mentioned experimental studies, it is reasonable to assume that the preferential arrangement of microfabric features in the till matrix is caused by syn- sedimentary pervasive shear strains, controlled partly by pore-water expulsion. The hydraulic conditions within the subglacial shear zone, influenced by the permeability of the till substratum and the deposits incorporated into the mesoscopic thrusts, could play an important role, increasing or reducing the pore pressure. Closed hydraulic conditions with a high pore pressure are required to maintain till deformation. Such conditions have been suggested in the model developed by Lash (1989) for the development of the closely-spaced fractures that cut the finely-brecciated till.

\section{Conclusions}

Mesoscopic and microscopic analyses of till show the following relationships between the geometry and density of mesoscopic fractures and microfabric features observed with SEM.

(1) The fracture density of the till at a mesoscale is reflected by the qualitative and quantitative characteristics of five microfabric features: type, shape, size, spatial arrangement, and porosity. When the fracture density increases, the microfabric features become more spatially arranged and dominated by elongated domains, interweaving bunches and fissure-like pores, while the porosity increases.

(2) The finely-brecciated till cut by closely spaced fractures is restricted to the damage zones that developed along mesoscopic thrusts, and also occurs in the lower part of the till unit that is underlain by low-permeability deposits. In both cases, a closed hydraulic system must have existed during thrusting of till and (sub) horizontal simple shearing along the contact between the active basal ice and the till.

(3) The shear strains of the till were accommodated by both localised and pervasive shear zones. The localised shear zones are represented by mesoscopic fractures and linear zones in which the microfabric features show a preferred arrangement. The spatial pattern of these localised shears corresponds to Riedel shears, P-type structures and C-S foliation. Pervasive shear zones occur at a microscale and are manifested in changes of the pore space in the matrix. This change involves reorientation 
of the pores and their elongation, as well as an increase in porosity. The change in pore space is often accompanied by reorientation of clay microaggregates.

(4) The positive correlations between increasing porosity, increasing spatial arrangement of pores, and increasing density of mesoscopic fracture shows the synsedimentary character of the pervasive shear strains of the till. These shear strains were accommodated by particulate flow. The hydraulic conditions within the subglacial shear zone controlled rheological differences of the till during deformation and thus influenced the rate of change of the microfabric features.

\section{Acknowledgements}

I thank Mark Tarplee and an anonymous reviewer for helpful comments.

\section{Appendix: Glossary}

\section{(see also Fig. 5)}

Domain: two or more microaggregates overlapping one another (Grabowska-Olszewska et al., 1984).

Open arrangement: edge-face or edge-edge loosely packed arrangement of microaggregates (Collins and McGown, 1974).

Microaggregate: main structural element of natural clayey deposits, composed of stacked, book-like arrangement of clay platelets (Grabowska-Olszewska et al., 1984).

Turbostratic arrangement: a closed arrangement of tightly packed and preferentially oriented microaggregates (Collins and McGown, 1974).

\section{References}

Antonellini, M., Aydin, A. \& Pollard, D.D., 1994. Microstructure of deformation bands in porous sandstones at Arches National Park. Journal of Structural Geology 16, 941-959.

Arch, J. \& Maltman A.J., 1990. Anisotropic permeability and tortuosity in deformed wet sediments. Journal of Geophysical Research 95, 9035-9046.

Arch, J., Maltman, A.J. \& Knipe R.J., 1988. Shear-zone geometries in experimentally deformed clays: the influence of water content, strain rate and primary fabric. Journal of Structural Geology 10, 91-99.
Bennett, R.H., Bryant, W.T. \& Hulbert, M.H. (Eds), 1991. Microstructure of fine-grained sediments. Springer-Verlag, New York, 582 pp.

Bolton, A.J., Maltman, A.J. \& Clennell, M.B., 1998. The importance of overpressure timing and permeability evolution in fine-grained sediments undergoing shear. Journal of Structural Geology 20, 1013-1022.

Borradaile, G.J., 1981. Particulate flow of rock and the formation of cleavage. Tectonophysics 72, 305-321.

Caine, J.S., Evans, J.P. \& Forster, C.B., 1996. Fault zone architecture and permeability structure. Geology 24, 1025-1028

Collins, K. \& McGown, A., 1974. The form and function of microfebric features in a variety of natural soils. Geotechnique 24, 223-254.

Grabowska-Olszewska, B., Osipov, V. \& Sokolov V., 1984. Atlas of the microstructure of clay soils. Wydawnictwo Naukowe PWN, Warszawa, 414 pp.

Hart, J.K., 2006. An investigation of subglacial processes at the microscale from Briksdalsbreen, Norway. Sedimentology 53, 125-146.

Kaczyński, R. \& Trzciński, J., 1992. The physical-mechanical and structural properties of boulder clays of the Vistula glaciation in the area of Poland. Geological Quarterly 36, 481-508.

Kilfeather, A.A. \& Van der Meer, J.J.M., 2008. Pore size, shape and connectivity in tills and their relationship to deformation processes. Quaternary Science Reviews 27, 250-266.

Kusky, T.M. \& Bradley, D.C., 1999. Kinematic analysis of melange fabric: examples and applications from the McHugh Complex, Kenai Peninsula, Alaska. Journal of Structural Geology 21, 1773-1796.

Lash, G., 1989. Documentation and significance of progressive microfabric changes in middle Ordovician trench mudstones. Geological Society of America Bulletin 101, 1268-1279.

Mahaney, W.C., Claridge, G. \& Campbell, L., 1996. Microtextures on quartz grains in tills from Antarctica. Palaeogeography, Palaeoclimatology, Palaeoecology 121, 89-103.

Maltman, A.J., 1987. Shear zones in argillaceous sediments - An experimental study. [In:] Jones, M.E. \& Preston, R.M.F. (Eds): Deformation of sediments and sedimentary rocks. Special Publications Geological Society London 29, 77-87.

Maltman, A.J. (Ed.), 1994. The geological deformation of sediments. Chapman and Hall, 362 pp.

Menzies, J., Van der Meer, J.J.M. \& Rose, J., 2006. Till as a glacial "tectomict", its internal architecture and the development of a "typing" method for till differentiation. Geomorphology 75, 172-200.

Murray, T. \& Dowdeswell, J.A., 1992. Water througflow and the physical effects of deformation on sedimentary glacier beds. Journal of Geophysical Research 97 (B6), 8993-9002.

Raymond, L.A., 1984. Classification of melanges. [In:] Raymond, L.A. (Ed.): Melanges: their nature, origin and significance. Geological Society of America Special Paper 198, 7-20. 
Rose, K.C. \& Hart, J.K., 2007. Subglacial comminution in the deforming bed: Inferences from SEM analysis. Sedimentary Geology 203, 87-97.

Ruszczyńska-Szenajch, H., Trzciński, J. \& Jarosińska, U., 2003. Lodgement till deposition and deformation investigated by macroscopic observation, thin-section analysis and electron microscope study at site Dębe, central Poland. Boreas 32, 399-415.

Ruszczyńska-Szenajch, H. \& Trzciński, J., 2009. Soft lodgement till deposition and syndepositional deformation, Anielinek, the Polish Lowlands. Canadian Journal of Earth Science 46, 67-82.

Stankowski, W. \& Krzyszkowski, D., 1991. Stratygrafia czwartorzędu okolic Konina [The Quaternary stratigraphy of the Konin area]. [In:] Stankowski, W. (Ed.): Przemiany środowiska geograficznego obszaru Konin-Turek. Wydawnictwo Naukowe UAM, Poznań, 11-31.

Statistica for Windows, 1998. Statsoft Inc., Tulsa.

Trzciński J., 1998. Ilościowa analiza mikrostrukturalna w skaningowym mikroskopie elektronowym (SEM) gruntów poddanych oddziaływaniu wody [Quantitative microstructural SEM analysis of soils influenced by pore water]. [In:] Grabowska-Olszewska, B. (Ed.): Geologia stosowana. Właściwości gruntów nienasyconych. Wydawnictwo Naukowe PWN, Warszawa, 113-150.

Trzciński, J., 2003. Mikrostruktury glin lodowcowych badane w skaningowym mikroskopie elektronowym [Scanning electron microscope analysis of microstructure in tills]. [In:] Harasimiuk, M. \& Terpiłowski, S. (Eds): Sedimentological analyses of glaciogenic deposits. UMCS Press, Lublin, 63-77.
Trzciński, J., 2008. Microstructure and physico-mechanical properties of tills in Poland. Geologija 50, 26-39.

Trzciński, J. \& Kaczyński, R., 1999. Microstructural nonhomogeneity of glacial tills. Visnyk Lviv. Univ. Ser. Mech. Match. 55, 152-157.

Vannucchi, P., Maltman, A., Bettelli, G. \& Clennell, B., 2003. On the nature of scaly fabric and scaly clay. Journal of Structural Geology 25, 673-688.

Widera, M., 1998. Ewolucja paleomorfologiczna i paleotektoniczna elewacji konińskiej [Paleomorphological and paleotectonical evolution of the Konin Elevation]. Geologos 3, 55-102.

Włodarski, W., 2000. Litologia, stratygrafia i glacitektonika dolnego i środkowego czwartorzędu [Lithology, stratigraphy and glaciotectonics]. [In:] Skoczylas, J. \& Biernacka, J. (Eds): Geologia i ochrona środowiska Wielkopolski. Przewodnik LXXI Zjazdu PTG. Bogucki Wydawnictwo Naukowe, Poznań, 112-121.

Włodarski, W., 2009. Analiza strukturalno-kinematyczna kompleksu deformacji glacitektonicznych w strefie rowu Kleczewa (elewacja konińska, wschodnia Wielkopolska) [Structural and kinematic analysis of glaciotectonic deformation complex within Kleczew Graben zone (Konin Elevation, Central Polish Lowland)]. Prace Państwowego Instytutu Geologicznego 194, 75-100.

Manuscript received 3 June 2009; revision accepted 9 March 2010. 